(c) American Dairy Science Association, 2003.

\title{
Effects of Tallow in Diets Based on Corn Silage or Alfalfa Silage on Digestion and Nutrient Use by Lactating Dairy Cows ${ }^{1}$
}

\author{
L. D. Ruppert, ${ }^{2}$ J. K. Drackley, D. R. Bremmer, ${ }^{3}$ and J. H. Clark \\ Department of Animal Sciences, \\ University of Illinois, Urbana 61801
}

\begin{abstract}
Six multiparous Holstein cows (average 31 days in milk; $36.3 \mathrm{~kg} / \mathrm{d}$ of milk) fitted with ruminal cannulas were used in a $6 \times 6$ Latin square with 21 -d periods to investigate the effects of diets that varied in forage source and amount of supplemental tallow. Isonitrogenous diets in a $2 \times 3$ factorial arrangement were based on either high corn silage (40:10 corn silage to alfalfa silage, $\%$ of dry matter) or high alfalfa silage (10:40 corn silage to alfalfa silage, $\%$ of dry matter) and contained 0 , 2 , or $4 \%$ tallow. Intakes of dry matter and total fatty acids were lower when cows were fed the high corn silage diet. Tallow supplementation linearly decreased dry matter intake. Milk yield was unaffected by diet; yields of milk fat and 3.5\% fat-corrected milk were higher for the high alfalfa silage diet but were unaffected by tallow. Milk fat percentage was higher for the high alfalfa silage and tended to decrease when tallow was added to the high corn silage diet. Contents of trans $-\mathrm{C}_{18: 1}$ isomers in milk fat were increased by high corn silage and tallow, and tended to be increased more when tallow was fed in the high corn silage diet. Ruminal $\mathrm{pH}$ and acetate:propionate were lower when high corn silage was fed. Ruminal acetate:propionate decreased linearly as tallow increased; the molar proportion of acetate was decreased more when tallow was added to the high corn silage diet. Ruminal liquid dilution rates were higher for the alfalfa silage diet; ruminal volume and solid passage rates were similar among diets. Total tract apparent digestibilities of dry matter, organic matter, crude protein, starch, energy, and total fatty acids were unaffected by diet. Digestibilities of neutral detergent fiber, acid detergent fiber, hemicellu-
\end{abstract}

Received February 19, 2002.

Accepted August 30, 2002.

Corresponding author: James K. Drackley; e-mail: drackley@ uiuc.edu.

${ }^{1}$ Supported by state and federal Hatch and Regional Research funds appropriated to the Illinois Agricultural Experiment Station.

${ }^{2}$ Current address: Wyffels Hybrids, 1124 Lenhart Rd, Springfield, IL 62707.

${ }^{3}$ Current address: Land O'Lakes Farmland Feed, N10768 Highway 73, Greenwood, WI 54437. lose, and cellulose were lower when high corn silage was fed. The high alfalfa silage diet increased intakes of metabolizable energy and N, and increased milk energy and productive $\mathrm{N}$. Tallow decreased the amount of $\mathrm{N}$ absorbed but had few other effects on utilization of energy or N. Tallow linearly increased concentrations of nonesterified fatty acids and cholesterol in plasma; cholesterol was increased by high alfalfa silage. Overall, forage source had more pronounced effects on production and metabolism than did tallow supplementation. Few interactions between forage source and tallow supplementation were detected except that ruminal fermentation and milk fat content were affected more negatively when tallow was fed in the high corn silage diet. (Key words: tallow, digestibility, corn silage, alfalfa silage)

\begin{abstract}
Abbreviation key: ADL = acid detergent lignin, FA = fatty acids, $\mathbf{E E}=$ ether extract, $\mathbf{M E}=$ metabolizable energy.
\end{abstract}

\section{INTRODUCTION}

Tallow is an abundant and low-cost source of supplemental fat used to increase dietary energy density for dairy cows. Data from several studies (Schauff et al., 1992; Elliott et al., 1993; Grummer et al., 1993) demonstrate that native tallow did not negatively affect ruminal fermentation, nutrient digestibilities, DMI, or milk production when supplemented in typically recommended amounts (e.g., 2 to $3 \%$ of DM) to high producing dairy cows. However, these data were obtained with basal diets consisting of alfalfa hay or silage as the principal forage. From a review of research data, Smith and Harris (1992) suggested that tallow and other rendered fats were more likely to depress DMI, milk yield, and milk fat percentage when supplemented to diets containing corn silage as the sole or predominant forage source. A recent experiment showed that supplementation of either tallow or choice white grease to a diet in which corn silage was the only forage decreased DMI, milk yield, milk fat percentage, and the ruminal acetate to propionate ratio, but neither fat source affected in situ DM or NDF disappearance (Onetti et al., 2001). 
Research has shown that corn silage and legume or grass forages may interact differently with various fat sources. Rapeseed oil decreased ruminal NDF digestion to a greater extent when supplemented to a diet based on corn silage than when it was supplemented to a diet in which grass hay was the forage source (Ben Salem et al., 1993). Tallow supplemented to a diet based on corn silage decreased milk fat percentage and fiber digestibilities compared with tallow supplementation to diets in which 25 or $50 \%$ of the corn silage DM was replaced with alfalfa hay (Smith et al., 1993).

Adequate intake of forage fiber is thought to be essential for optimal ruminal fermentation and nutrient digestibilities when supplemental fats are fed (Jenkins et al., 1998). The nature of the potential interaction between forage sources and fat supplementation is not clear. Corn silage and alfalfa silage differ markedly as forage sources (Broderick, 1985). Factors that could contribute to divergent responses to fat supplementation between corn silage and alfalfa silage include, among others, differences in amount and composition of the plant cell wall, which lead to differences in rate and extent of cell wall digestibility (Allen and Mertens, 1988); differences in starch content, which can impact rate of VFA production in the rumen and ruminal $\mathrm{pH}$ (Allen, 1997); and differences in forage particle size, which may affect rumination (Allen and Mertens, 1988), saliva flow (Allen, 1997), and possible interactions with rumen-available fat sources (Jenkins et al., 1998; Lewis et al., 1999). Furthermore, digestibility of long-chain fatty acids (FA) from a fat source may be affected by the nature of the basal diet to which the fat source is added (Grum et al., 1996).

The objective of this experiment was to quantify nutrient intakes, nutrient digestibilities, ruminal fermentation, milk production and composition, and energy and $\mathrm{N}$ balances of lactating dairy cows fed two ratios of corn silage and alfalfa silage with or without supplementation of tallow. Our hypothesis was that a diet based primarily on corn silage would alter ruminal fermentation and digestive characteristics compared with a diet based primarily on alfalfa silage, and that cows fed the high corn silage diet would be more susceptible to negative effects of tallow on DMI, ruminal fermentation, nutrient digestibilities, and milk yield and composition.

\section{MATERIALS AND METHODS}

\section{Management of Cows and Experimental Design}

All procedures were conducted under protocols approved by the University of Illinois Laboratory Animal Care Advisory Committee. Six multiparous cows were fitted with ruminal cannulas prior to parturition. The ruminal cannulas (Bar Diamond, Inc., Parma, ID) were made of soft plastic and had an inside diameter of 10.2 $\mathrm{cm}$. At the start of the experiment the cows averaged 31 DIM (range 10 to $57 \mathrm{~d}$ ). Cows were housed in a barn with individual stanchions, bedded with long straw, and allowed to exercise in a dry lot from 0600 to 0900 $\mathrm{h}$ daily, accept during the last $4 \mathrm{~d}$ of each period. Cows were fed TMR twice daily for ad libitum intake and were milked twice daily at 0530 and $1700 \mathrm{~h}$. The experiment was conducted during May through September of 1994.

The experimental design was a modified $6 \times 6$ Latin square with 21-d periods. Treatment diets were in a 2 $\times 3$ factorial arrangement with two forage types and three amounts of tallow. Treatments were 1) high corn silage ( $40 \%$ corn silage, $10 \%$ alfalfa silage; percentage of total dietary DM), 0\% supplemental tallow; 2) high corn silage, $2 \%$ tallow; 3 ) high corn silage, $4 \%$ tallow; 4) high alfalfa silage ( $40 \%$ alfalfa silage, $10 \%$ corn silage; percentage of total dietary DM), $0 \%$ tallow; 5) high alfalfa silage, $2 \%$ tallow; and 6) high alfalfa silage, $4 \%$ tallow. The tallow (Max-Fat; Maxco, Inc., Green Bay, WI) was analyzed to contain $87 \%$ total FA, consisting of $2.3 \% \mathrm{C}_{14: 0}, 0.5 \% \mathrm{C}_{14: 1}, 24.2 \% \mathrm{C}_{16: 0}, 2.9 \% \mathrm{C}_{16: 1}, 0.8 \%$ $\mathrm{C}_{17: 0}, 17.4 \% \mathrm{C}_{18: 0}, 3.3 \%$ total trans- $\mathrm{C}_{18: 1}, 40.1 \%$ cis- $\mathrm{C}_{18: 1}$, $5.3 \% \mathrm{C}_{18: 2}, 0.4 \% \mathrm{C}_{18: 3}$, and $3.3 \%$ other FA. Ingredient composition of the diets is shown in Table 1 . Diets were formulated to meet or exceed the nutrient requirements for lactating cows stated by the NRC (1989). Each 21$\mathrm{d}$ period consisted of $14 \mathrm{~d}$ for adjustment to treatment, followed by $7 \mathrm{~d}$ of sample collection. Because we reasoned that ruminal adjustments to the different forage types would be more pronounced than those to different amounts of tallow within diets of the same forage type, treatment sequences were designed so that three cows received all three tallow treatments within each forage in sequential periods, and then were switched to the opposite forage. One extra week of adjustment to the alternative forage was allowed between periods 3 and 4 .

\section{DMI, Nutrient Fractions, Milk Yield, and Milk Composition}

Feed offered and refused was measured and recorded daily. Orts (10\% of daily refusal) and dietary ingredients were sub-sampled for each cow during the last 5 $d$ of each period and samples were composited on a proportional basis according to amounts fed and refused each day. Composite samples then were dried at $55^{\circ} \mathrm{C}$ and ground in a Wiley mill with a 1-mm screen (Arthur H. Thomas, Philadelphia, PA). Dried samples of feeds and orts were analyzed for $\mathrm{DM}, \mathrm{OM}\left(600^{\circ} \mathrm{C}\right.$ for 8 hours $)$, CP (AOAC, 1984), ether extract (EE; AOAC, 1984), energy (1261 Isoperibol Calorimeter; Parr Instrument 
Table 1. Ingredient composition of total mixed diets.

\begin{tabular}{|c|c|c|c|c|c|c|}
\hline \multirow[b]{3}{*}{ Ingredient } & \multicolumn{6}{|c|}{ Diet } \\
\hline & \multicolumn{3}{|c|}{ High corn silage } & \multicolumn{3}{|c|}{ High alfalfa silage } \\
\hline & $0 \%$ Fat & $2 \%$ Fat & $4 \%$ Fat & $0 \%$ Fat & $2 \%$ Fat & $4 \%$ Fat \\
\hline & & & $-(\%$ & M) & 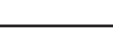 & \\
\hline Alfalfa silage & 10.00 & 10.00 & 10.00 & 40.00 & 40.00 & 40.00 \\
\hline Corn silage & 40.00 & 40.00 & 40.00 & 10.00 & 10.00 & 10.00 \\
\hline Soybean meal & 21.64 & 22.14 & 22.64 & 13.79 & 14.30 & 14.79 \\
\hline Ground shelled corn & 24.93 & 22.42 & 19.92 & 33.77 & 31.26 & 28.77 \\
\hline Tallow ${ }^{1}$ & 0.00 & 2.00 & 4.00 & 0.00 & 2.00 & 4.00 \\
\hline Limestone & 1.33 & 1.31 & 1.30 & 0.35 & 0.35 & 0.35 \\
\hline Dicalcium phosphate & 0.84 & 0.86 & 0.87 & 0.99 & 0.99 & 0.99 \\
\hline Magnesium oxide & 0.05 & 0.06 & 0.06 & 0.08 & 0.08 & 0.08 \\
\hline Sodium chloride & 0.31 & 0.31 & 0.31 & 0.12 & 0.12 & 0.12 \\
\hline Sodium bicarbonate & 0.75 & 0.75 & 0.75 & 0.75 & 0.75 & 0.75 \\
\hline Mineral and vitamin mixture ${ }^{2}$ & 0.15 & 0.15 & 0.15 & 0.15 & 0.15 & 0.15 \\
\hline
\end{tabular}

Co., Moline, IL), FA (Sukhija and Palmquist, 1988; Schauff et al., 1992), NDF (using $\alpha$-amylase; Van Soest et al., 1991), ADF (Van Soest et al., 1991), acid detergent lignin (ADL; Van Soest et al., 1991), cellulose (ADF minus ADL), hemicellulose (NDF minus ADF), starch (Kartchner and Theurer, 1981), and soluble residue (neutral detergent solubles minus $\mathrm{CP}$ and $\mathrm{EE}$ ). Chemical composition of total diets (Table 2) was calculated from analyses of individual ingredients and their proportions in the total diet.

Milk weights were recorded daily at each milking. Milk was sampled at each milking during the last $7 \mathrm{~d}$ of each period and composited daily for each cow according to milk production. Milk samples were preserved with 2-bromo-2-nitropropane-1,3-diol and stored at $4^{\circ} \mathrm{C}$ until analysis. Two composite samples were pre-

Table 2. Chemical composition of forages and total mixed diets.

\begin{tabular}{|c|c|c|c|c|c|c|c|c|}
\hline \multirow[b]{3}{*}{ Component } & \multicolumn{2}{|c|}{ Forage } & \multicolumn{6}{|c|}{ Total diets ${ }^{1}$} \\
\hline & \multirow{2}{*}{$\begin{array}{l}\text { Corn } \\
\text { silage }\end{array}$} & \multirow{2}{*}{$\begin{array}{l}\text { Alfalfa } \\
\text { silage }\end{array}$} & \multicolumn{3}{|c|}{ High corn silage } & \multicolumn{3}{|c|}{ High alfalfa silage } \\
\hline & & & $0 \%$ Fat & $2 \%$ Fat & $4 \%$ Fat & $0 \%$ Fat & $2 \%$ Fat & $4 \%$ Fat \\
\hline DM, \% & 37.4 & 50.9 & 57.1 & 57.4 & 57.5 & 65.6 & 65.2 & 65.4 \\
\hline $\mathrm{OM}$ & 94.8 & 90.3 & 92.5 & 92.0 & 92.1 & 92.0 & 92.1 & 91.9 \\
\hline $\mathrm{CP}$ & 7.1 & 18.1 & 17.6 & 17.5 & 17.6 & 17.6 & 18.0 & 18.1 \\
\hline $\mathrm{NDF}$ & 44.7 & 57.0 & 33.6 & 34.1 & 33.5 & 37.7 & 38.2 & 37.2 \\
\hline $\mathrm{ADF}$ & 27.8 & 42.9 & 18.2 & 18.1 & 18.2 & 22.5 & 22.6 & 22.8 \\
\hline Forage NDF & $\ldots$ & $\ldots$ & 23.6 & 23.6 & 23.6 & 27.3 & 27.3 & 27.3 \\
\hline Forage ADF & & $\ldots$ & 15.4 & 15.4 & 15.4 & 19.9 & 19.9 & 19.9 \\
\hline Hemicellulose & 16.9 & 14.1 & 15.5 & 16.0 & 15.3 & 15.3 & 15.6 & 15.4 \\
\hline $\mathrm{ADL}^{2}$ & 3.9 & 8.5 & 2.9 & 2.9 & 2.9 & 4.3 & 4.2 & 4.5 \\
\hline Cellulose & 23.9 & 34.4 & 15.3 & 15.2 & 15.2 & 18.2 & 18.4 & 18.3 \\
\hline Soluble residue & 44.4 & 21.7 & 45.5 & 43.3 & 41.2 & 41.2 & 38.1 & 35.3 \\
\hline Starch & 36.0 & 1.2 & 32.3 & 30.4 & 30.1 & 27.9 & 26.0 & 25.7 \\
\hline $\mathrm{NFC}^{3}$ & 39.3 & 12.1 & 38.1 & 35.3 & 33.3 & 33.5 & 30.3 & 27.3 \\
\hline Ether extract & 3.8 & 3.2 & 3.2 & 5.1 & 7.7 & 3.3 & 5.6 & 8.3 \\
\hline Total FA & 2.8 & 2.0 & 2.6 & 4.0 & 5.1 & 2.8 & 3.9 & 5.5 \\
\hline Gross energy & 4.6 & 4.5 & 4.4 & 4.5 & 4.6 & 4.4 & 4.5 & 4.6 \\
\hline
\end{tabular}

${ }^{1}$ Calculated from analyses of individual ingredients and proportions in total dietary DM.

${ }^{2}$ Acid detergent lignin.

${ }^{3}$ Nonfiber carbohydrates. NFC $=100-\mathrm{NDF} \%-\mathrm{CP} \%-$ ether extract $\%-$ ash $\%$.

${ }^{4}$ Fatty acids. 
pared for each cow during each period (representing the first $4 \mathrm{~d}$ and the last $3 \mathrm{~d}$ of each 7-d sampling period) in proportion to daily yields of milk. Composite samples of milk were analyzed for contents of $\mathrm{CP}$, true protein, casein, NPN, and fat by mid-infrared spectroscopy (New York DHIA Laboratory, Ithaca, NY). Noncasein N was determined by Kjeldahl analysis of the filtrate after precipitation with $10 \%$ acetic acid and $1 N$ sodium acetate (IDF, 1964). Casein $\mathrm{N}$ was calculated as the difference between total N and noncasein N, NPN was calculated as the difference between total $\mathrm{N}$ and true protein $\mathrm{N}$, and whey protein $\mathrm{N}$ was calculated as the difference between true protein $\mathrm{N}$ and casein $\mathrm{N}$. Composite samples of milk were analyzed for FA profiles by GLC of methyl esters (Sukhija and Palmquist, 1988) and content of glycerol was calculated as described previously (Schauff et al., 1992). Milk energy was determined in composite samples by bomb calorimetry (1261 Isoperibol Calorimeter; Parr Instrument Co., Moline, IL).

\section{Ruminal Fermentation, Passage Rate Constants, and Total Tract Digestibilities}

Every $3 \mathrm{~h}$ during the last $3 \mathrm{~d}$ of each period, ruminal fluid $(40 \mathrm{ml})$ was collected from several locations in the ventral rumen in proximity to the ruminal cannula of each cow via a suction pump. On each day, the sample schedule was moved back by $1 \mathrm{~h}$ so that each hour of the day was represented. Ruminal fluid $\mathrm{pH}$ was determined immediately with a glass electrode. Samples then were acidified to $\mathrm{pH} 2$ with $50 \% \mathrm{H}_{2} \mathrm{SO}_{4}$, centrifuged at 27,000 $\times g$ for $10 \mathrm{~min}$, and the supernatant was frozen. The samples later were thawed and equal amounts of hourly samples were composited by cow within period. Composite samples were analyzed for concentrations of VFA and $\mathrm{NH}_{3}-\mathrm{N}$. The VFA in the supernatant were determined by automated GLC (Varian Model 4600; Varian, Palo Alto, CA) according to procedures of Klusmeyer et al. (1987). Concentration of $\mathrm{NH}_{3}-\mathrm{N}$ was determined according to procedures of Chaney and Marbach (1962).

A pulse dose of $50 \mathrm{~g}$ of $\mathrm{Na}$ Co-EDTA, dissolved in 500 $\mathrm{ml}$ of water, was placed in the rumen at $1500 \mathrm{~h}$ on $\mathrm{d}$ 18 of each period. Samples of ruminal fluid taken every $3 \mathrm{~h}$ for the next $24 \mathrm{~h}$, as described for $\mathrm{VFA}$ and $\mathrm{NH}_{3}$ $\mathrm{N}$ analysis, were analyzed for Co concentration using atomic absorption spectrophotometry (Model 2380; Perkin-Elmer, Norwalk, CT). Dilution rate of ruminal fluid was calculated using the procedure described by Udén et al. (1980).

On $\mathrm{d} 18$, any feed remaining in the feed bunks was removed $1 \mathrm{~h}$ before the evening feeding. A solution of $\mathrm{Yb}$ acetate $(2.5 \mathrm{~g}$ of $\mathrm{Yb})$ was sprayed onto $2.5 \mathrm{~kg}$ of TMR, and the treated TMR was fed to the cows at $1700 \mathrm{~h}$. Any feed not consumed within 15 min was removed from the feed bunk and placed into the rumen via the ruminal cannula. The remaining TMR for that feeding then was placed into the feed bunk, and cows were allowed free access to their feed. Eight samples of ruminal digesta were taken at 6 -h intervals starting $3 \mathrm{~h}$ after dosing. Ruminal digesta samples were dried at $55^{\circ} \mathrm{C}$ and ground through a $1-\mathrm{mm}$ screen in a Wiley mill. Ruminal digesta samples were ashed, solubilized in a solution of $3 \mathrm{~N} \mathrm{HCl}$ and $3 \mathrm{~N} \mathrm{HNO}_{3}$, diluted 3:8 (vol/ vol) with $1 \mathrm{~N} \mathrm{HCl}$, and analyzed for the concentration of $\mathrm{Yb}$ by atomic absorption spectrophotometry (Model 2380; Perkin-Elmer) as described by Ellis and Lascano (1982). Passage rate of ruminal particulate matter was calculated by regressing the natural logarithm of $\mathrm{Yb}$ concentration on time after dosing.

Cows were dosed with $20 \mathrm{~g}$ of chromic oxide powder via the ruminal cannula twice daily at 12 -h intervals during $\mathrm{d} 13$ to 21 of each period to measure apparent total tract digestibilities of nutrient fractions. Fecal grab samples were collected at 12 -h intervals during $d$ 17 to 21 of each period and frozen until the end of the period. Samples then were thawed and pooled into one sample on an equal wet weight basis for each cow. The composite samples were dried at $55^{\circ} \mathrm{C}$ and ground in a Wiley mill (1-mm screen). The content of chromium in fecal samples was determined by atomic absorption spectrophotometry (Williams et al., 1962). Contents in feces of DM, ash, OM, CP, ADF, NDF, ADL, cellulose, hemicellulose, EE, soluble residue, starch, FA, and energy were measured as described for feeds and orts.

\section{Utilization of Energy and $\mathrm{N}$}

Urine was collected daily during $\mathrm{d} 17$ to 21 of each period into polyethylene containers via plastic urinary cups (Fellner et al., 1988) that were placed around the vulva on d 16. To minimize loss of $\mathrm{NH}_{3}, 220 \mathrm{ml}$ of concentrated $\mathrm{HCl}$ was added daily to each container. Urine was weighed, the weight was recorded, and $5 \%$ of the daily urinary output was stored at $4{ }^{\circ} \mathrm{C}$ until the samples were composited at the end of each period. The composited samples then were frozen at $-20^{\circ} \mathrm{C}$ until analysis. Urine was analyzed for contents of energy (1261 Isoperibol Calorimeter; Parr Instrument Co.) and $\mathrm{N}$ (AOAC, 1984) to determine utilization of energy and N. Methane energy was estimated from amounts of digested cellulose, hemicellulose, and soluble residue using the regression equation of Moe and Tyrrell (1979). Apparent metabolizable energy (ME) intake was estimated by subtracting gross energy lost in feces, urine, and methane from gross energy in feed consumed. Maintenance requirements for ME were calculated according to NRC (1989); intake of ME above maintenance (i.e., ME available for milk production) was estimated 
by subtracting maintenance ME from ME intake. Efficiency was calculated by dividing milk energy output (energy value of milk determined by bomb calorimetry times milk yield) by apparent ME intake above maintenance. Retained $\mathrm{N}$ was calculated by subtracting $\mathrm{N}$ in feces, urine, and milk from $\mathrm{N}$ intake. Productive $\mathrm{N}$ was calculated as the sum of $\mathrm{N}$ retained in the body and $\mathrm{N}$ secreted in milk.

\section{Blood Sampling and Analysis}

Blood was sampled from each cow by puncture of the coccygeal vein or artery before and $3 \mathrm{~h}$ after the a.m. feeding on d 21 of each period. Samples were collected into evacuated tubes (Vacutainer; Becton Dickinson and Co., Rutherford, NJ) containing heparin and were placed immediately on ice. Tubes then were centrifuged at $14,000 \times g$ for $15 \mathrm{~min}$ to obtain plasma, which was collected and frozen at $-20^{\circ} \mathrm{C}$ until analysis for concentrations of NEFA (Johnson and Peters, 1993), glucose (kit number 315; Sigma Chemical Co., St. Louis, MO), BHBA (kit number 310-UV; Sigma Chemical Co.), total cholesterol (kit number 352; Sigma Chemical Co.), and urea N (Chaney and Marbach, 1962).

\section{Statistical Analysis}

Repeated measurements (e.g., DMI, milk yield, and milk composition) from the week of data collection were reduced to period means for each cow before statistical analysis. Data were subjected to ANOVA for a Latin square design using the general linear models procedures of SAS (Fruend and Littell, 1981; SAS, 1985). The model contained effects of cow, period, forage type, tallow amount, and the interaction of forage and tallow. Sums of squares for tallow were partitioned into linear and quadratic effects of increasing tallow amount. The effects of sampling time on ruminal $\mathrm{pH}$ were analyzed using a split plot in time design. Within forage types, cows were assigned to amounts of tallow in sequences that were balanced for residual tallow effects (i.e., carryover effects) so that each tallow treatment amount was preceded in the design an equal number of times by each of the other treatments (Cochran and Cox, 1957). Differences of $P<0.05$ were considered significant. Probability values between 0.05 and 0.10 are discussed as trends.

\section{RESULTS AND DISCUSSION}

\section{Nutrient Composition of Diets}

Chemical composition of the forages and TMR is shown in Table 2. Diets were formulated on the basis of initial samples of forages that contained similar amounts of NDF; consequently, we anticipated that keeping the forage to concentrate ratio the same by altering only the DM ratio of forages between diets also would result in nearly equal dietary concentrations of NDF. However, NDF in the alfalfa silage actually fed throughout the experiment was greater than that of the corn silage (Table 2); consequently, the high alfalfa silage diets contained approximately 3.7 percentage units more NDF from forage than did the high corn silage diets. Both diets exceeded the minimum recommendations for NDF from forage (NRC, 1989). Contents of CP were similar within the high corn silage diets, averaging $17.5 \%$. High alfalfa silage diets supplemented with tallow contained slightly more CP than the unsupplemented diet (17.6 vs. 18.0 and 18.1). Concentrations of $\mathrm{ADF}, \mathrm{ADL}$, and cellulose were lower in the high corn silage diets; hemicellulose content was similar among treatments, averaging $15.5 \%$. High corn silage diets had higher contents of starch than high alfalfa silage diets (30.9\% vs. $26.5 \%)$ because of the higher concentration of starch in corn silage, which offset the greater starch from ground shelled corn in the high alfalfa silage diets. Concentrations of $\mathrm{EE}$ averaged $3.2,5.4$, and $8.0 \%$ for diets supplemented with 0,2 , and $4 \%$ tallow, respectively. Total FA concentration increased with tallow supplementation, averaging 2.7, 3.9 , and $5.4 \%$. Each increment of tallow supplementation increased gross energy concentrations by an average of $0.1 \mathrm{Mcal} / \mathrm{kg}$.

In the following presentation and discussion of results, effects are discussed separately for the main effects of tallow supplementation and forage type. Given the inherent confounding in experiments that attempt to compare effects of different forages (Oba and Allen, 1999) and the myriad of differences between corn silage and alfalfa silage as discussed previously, "forage effects" should be interpreted as differences between basal diets due to the different forage base. Our main focus was on identification of interactions between tallow and diets based primarily on either corn silage or alfalfa silage.

\section{Intake of Nutrients}

Tallow effects. The DMI decreased linearly with increasing tallow supplementation (Table 3 ), regardless of forage type. Intakes of total FA, total $\mathrm{C}_{16} \mathrm{FA}$, and total $\mathrm{C}_{18}$ FA increased linearly as the amount of dietary tallow was increased. Effects of tallow supplementation on DMI have been variable. Clapperton and Steele (1983) reported that DMI was decreased when unprotected tallow was fed as 6.7 or $10 \%$ of the dietary DM. Elliott et al. (1993) reported a $3 \mathrm{~kg} / \mathrm{d}$ decrease in DMI by lactating cows fed a diet containing $5 \%$ tallow compared 
Table 3. Intakes of DM and fatty acids (FA), milk yield, and milk composition for cows fed diets differing in forage and amount of supplemental fat.

\begin{tabular}{|c|c|c|c|c|c|c|c|c|c|c|c|}
\hline \multirow[b]{3}{*}{ Item } & \multicolumn{6}{|c|}{ Diets } & \multirow[b]{3}{*}{ SEM } & \multicolumn{4}{|c|}{ Significance of effects $(P)$} \\
\hline & \multicolumn{3}{|c|}{ High corn silage } & \multicolumn{3}{|c|}{ High alfalfa silage } & & \multirow[b]{2}{*}{ Forage } & \multicolumn{2}{|c|}{ Fat } & \multirow{2}{*}{$\begin{array}{l}\text { Fat } \times \\
\text { forage }\end{array}$} \\
\hline & $0 \%$ Fat & $2 \%$ Fat & $4 \%$ Fat & $0 \%$ Fat & $2 \%$ Fat & $4 \%$ Fat & & & Linear & Quadratic & \\
\hline DMI, kg/d & 22.6 & 21.4 & 21.4 & 24.8 & 23.6 & 22.9 & 0.4 & $<0.01$ & $<0.01$ & 0.26 & 0.68 \\
\hline \multicolumn{12}{|l|}{ FA Intake, g/d } \\
\hline Total & 586 & 858 & 1098 & 695 & 914 & 1250 & 50 & 0.02 & $<0.01$ & 0.63 & 0.64 \\
\hline Total $\mathrm{C}_{16}$ & 102 & 208 & 278 & 128 & 241 & 358 & 13 & $<0.01$ & $<0.01$ & 0.46 & 0.10 \\
\hline Fat, \% & 3.18 & 2.89 & 2.70 & 3.39 & 3.44 & 3.41 & 0.11 & $<0.01$ & 0.06 & 0.95 & 0.12 \\
\hline Fat, $\mathrm{kg} / \mathrm{d}$ & 1.03 & 0.97 & 0.91 & 1.12 & 1.14 & 1.17 & 0.04 & $<0.01$ & 0.38 & 0.94 & 0.21 \\
\hline $3.5 \% \mathrm{FCM}^{1}, \mathrm{~kg} / \mathrm{d}$ & 30.6 & 30.0 & 29.1 & 32.7 & 32.8 & 33.7 & 0.9 & $<0.01$ & 0.81 & 0.88 & 0.40 \\
\hline $\mathrm{CP}, \%$ & 3.11 & 2.89 & 2.99 & 3.14 & 3.09 & 3.01 & 0.08 & 0.19 & 0.13 & 0.20 & 0.33 \\
\hline $\mathrm{CP}, \mathrm{kg} / \mathrm{d}$ & 1.01 & 0.96 & 1.01 & 1.01 & 1.02 & 1.03 & 0.03 & 0.07 & 0.71 & 0.17 & 0.72 \\
\hline
\end{tabular}

${ }^{1} 3.5 \% \mathrm{FCM}=(0.4324 \times \mathrm{kg}$ milk $)+(16.216 \times \mathrm{kg}$ fat $)$.

with cows fed diets containing 0 or $2.5 \%$ tallow in addition to high-oil corn. In contrast, when unprotected tallow was fed at $6 \%$ or less of the dietary DM in other experiments, DMI was not decreased (Clapperton and Steele, 1983; Schauff et al., 1992; Grummer et al., 1993). Our study provides no evidence that forage base is a significant factor in whether tallow decreases DMI in lactating cows.

Forage effects. Cows fed the high alfalfa silage diet had significantly greater DMI than those fed the high corn silage diet (Table 3), despite the higher total dietary NDF content of the high alfalfa silage diet. Intakes of total FA and total $\mathrm{C}_{16} \mathrm{FA}$ were higher when cows were fed alfalfa silage-based diets because of the greater DMI. Dietary forage source had no effect on intake of total $\mathrm{C}_{18} \mathrm{FA}$. When corn silage-based or alfalfa-based diets were compared in other experiments, DMI was not affected significantly (Broderick, 1985; Charmley et al., 1993). The DMI was similar for cows fed a corn silage-based diet or two diets with alfalfa silage added to replace a portion of the corn silage (Smith et al., 1993).

\section{Milk Yield and Composition}

Tallow effects. Milk yield was not affected when tallow was supplemented to the diet (Table 3). Supplementing $5 \%$ choice white grease to diets for lactating dairy cows increased milk yield (Drackley et al., 1994) whereas addition of 1 to $10 \%$ tallow in other experiments (Clapperton and Steele, 1983; Schauff et al., 1992; Elliott et al., 1993; Grummer et al., 1993) did not affect milk yields significantly.

The content of milk fat tended $(P=0.06)$ to decrease linearly as dietary tallow supplementation increased (Table 3). Although not statistically significant, the ten- dency $(P=0.12)$ for a tallow by forage interaction indicates that tallow tended to decrease milk fat content to a greater extent when fed in the high corn silage diet than when fed in the high alfalfa silage diet. Yield of $3.5 \%$ FCM was not affected by tallow supplementation. Responses of milk fat percentages to tallow supplementation have varied, including increases (Schauff et al., 1992), decreases (Elliott et al., 1993; Onetti et al., 2001), and no effect (Grummer et al., 1993; Jenkins et al., 1998).

Means for content of $\mathrm{CP}$ (i.e., total $\mathrm{N} \times 6.38$ ) in milk (Table 3) decreased as dietary tallow increased, although the linear trend was not significant $(P=0.13)$. The yield of CP in milk was not affected by tallow supplementation. Milk protein percentage was unchanged (Clapperton and Steele, 1983; Palmquist, 1991; Schauff et al., 1992) or decreased (Clapperton and Steele, 1983; Elliott et al., 1993; Jenkins et al., 1998) when tallow was fed to lactating dairy cows. The tendency for decreased CP in milk was attributable to tendencies for linear decreases in contents of true protein $(P=0.13)$ and casein $(P=0.07)$ as dietary tallow increased (Table 4). Contents of whey protein and NPN were not affected by tallow supplementation. When expressed as percentages of total $\mathrm{N}$, content of true protein tended $(P=$ $0.08)$ to decrease linearly, and NPN tended $(P=0.08)$ to increase linearly, as tallow supplementation increased. Yields of milk N components were not affected by tallow supplementation. These effects of tallow supplementation were similar to previously reported effects of fat supplementation (DePeters et al., 1989).

The composition of milk fat was altered significantly as tallow was supplemented to the diets (Table 5). The content of $\mathrm{C}_{4: 0}$ tended $(P=0.10)$ to decrease linearly with increasing tallow supplementation, but the tendency $(P$ $=0.08$ ) for a tallow by forage interaction revealed that 
Table 4. Composition and yield of nitrogenous components in milk from cows fed diets differing in forage and amount of supplemental fat.

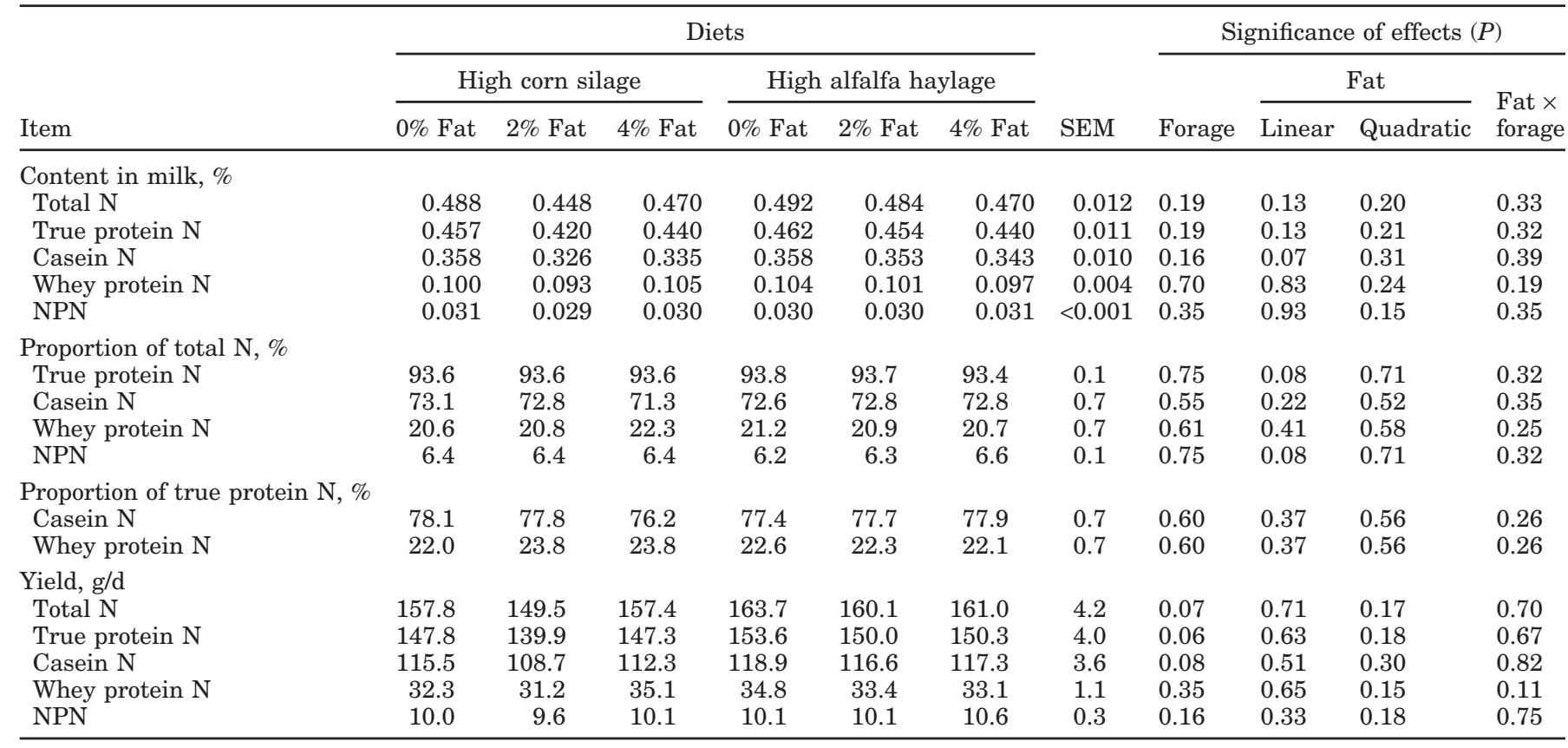

the decrease occurred only in the high corn silage diet. Short- and medium-chain FA in milk $\left(\mathrm{C}_{6: 0}\right.$ to $\mathrm{C}_{10: 0}$ and $\mathrm{C}_{14: 0}$ to $\left.\mathrm{C}_{15: 0}\right)$ decreased linearly $(P<0.01)$ as tallow supplementation increased. Quadratic effects existed for $\mathrm{C}_{12: 0}$ and $\mathrm{C}_{16: 0}$ because the decreased contents compared with control values were similar for either level of tallow supplementation. Similarly, a quadratic effect of tallow supplementation existed for the content of
$\mathrm{C}_{18: 0}$ in milk fat; contents were increased by addition of $2 \%$ tallow but not increased further by $4 \%$ tallow. Contents of $\mathrm{C}_{17: 0}$, trans- $\mathrm{C}_{18: 1}$, and cis- $\mathrm{C}_{18: 1}$ increased linearly as supplemental tallow increased. These changes may reflect the influence of FA contained in tallow $\left(\mathrm{C}_{17: 0}\right.$, trans- $\left.\mathrm{C}_{18: 1}\right)$ or produced by intestinal or mammary desaturation of $\mathrm{C}_{18: 0}$ produced after ruminal biohydrogenation of unsaturated FA in tallow. The content

Table 5. Composition of milk fat from cows fed diets differing in forage and amount of supplemental fat.

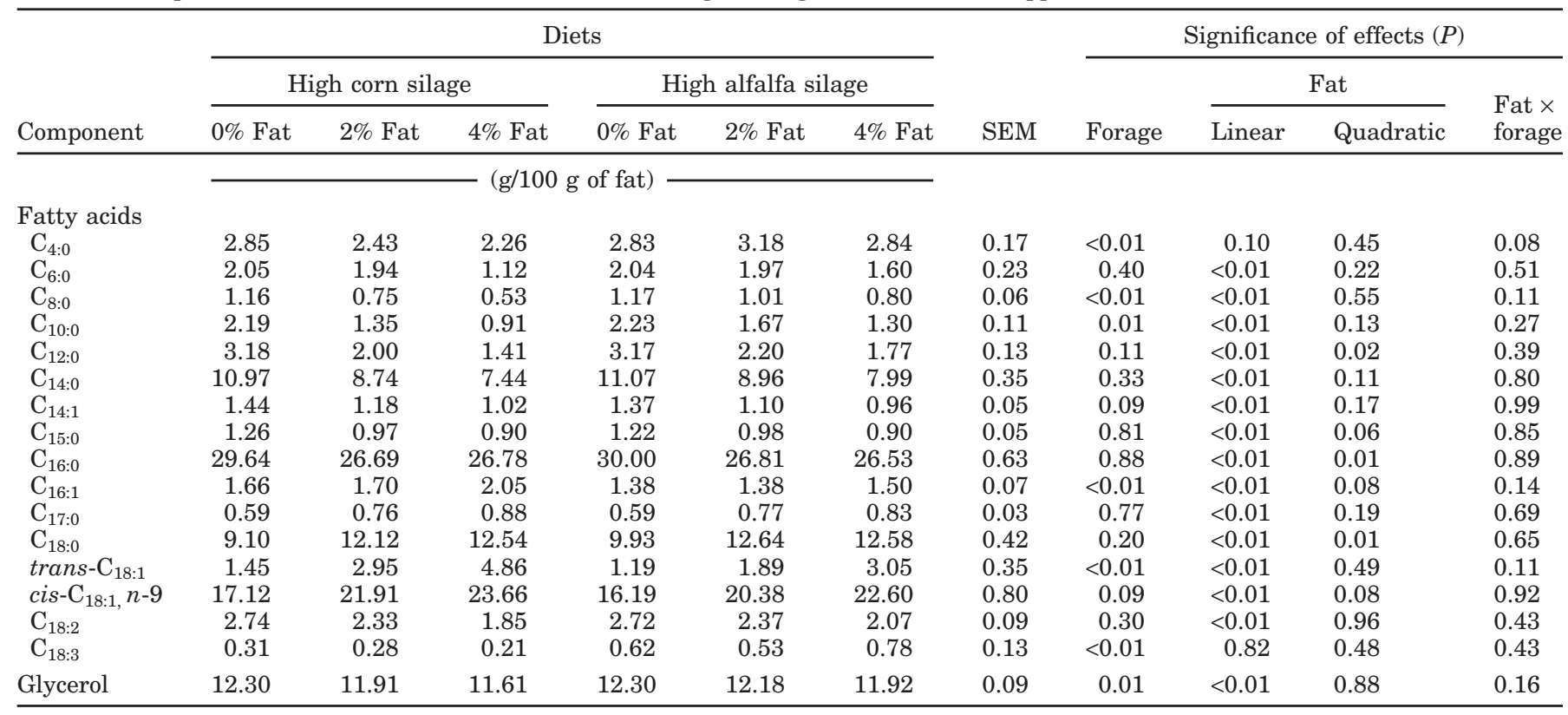


Table 6. Yields of fatty acids and glycerol in milk from cows fed diets differing in forage and amount of supplemental fat.

\begin{tabular}{|c|c|c|c|c|c|c|c|c|c|c|c|}
\hline \multirow[b]{3}{*}{ Component } & \multicolumn{6}{|c|}{ Diets } & \multirow[b]{3}{*}{ SEM } & \multicolumn{4}{|c|}{ Significance of effects $(P)$} \\
\hline & \multicolumn{3}{|c|}{ High corn silage } & \multicolumn{3}{|c|}{ High alfalfa silage } & & \multirow[b]{2}{*}{ Forage } & \multicolumn{2}{|c|}{ Fat } & \multirow{2}{*}{$\begin{array}{l}\text { Fat } \times \\
\text { forage }\end{array}$} \\
\hline & $0 \%$ Fat & $2 \%$ Fat & $4 \%$ Fat & $0 \%$ Fat & $2 \%$ Fat & $4 \%$ Fat & & & Linear & Quadratic & \\
\hline & & & $(\xi$ & & & & & & & & \\
\hline \multicolumn{12}{|l|}{ Fatty acids } \\
\hline $\mathrm{C}_{4: 0}$ & 29.2 & 23.7 & 20.8 & 31.9 & 36.1 & 33.6 & 2.26 & $<0.01$ & 0.16 & 0.61 & 0.07 \\
\hline $\mathrm{C}_{6: 0}$ & 21.0 & 20.3 & 10.3 & 23.1 & 22.4 & 19.2 & 2.84 & 0.07 & 0.02 & 0.25 & 0.41 \\
\hline $\mathrm{C}_{8: 0}$ & 12.0 & 7.5 & 4.9 & 13.3 & 11.5 & 9.6 & 0.90 & $<0.01$ & $<0.01$ & 0.61 & 0.19 \\
\hline $\mathrm{C}_{10 \cdot 0}$ & 22.4 & 13.5 & 8.3 & 25.3 & 19.0 & 15.8 & 1.58 & $<0.01$ & $<0.01$ & 0.23 & 0.37 \\
\hline $\mathrm{C}_{12.0}$ & 32.6 & 19.8 & 12.8 & 35.9 & 25.1 & 21.3 & 1.95 & $<0.01$ & $<0.01$ & 0.07 & 0.41 \\
\hline $\mathrm{C}_{14: 0}$ & 112.2 & 85.0 & 66.8 & 124.6 & 102.1 & 94.7 & 5.87 & $<0.01$ & $<0.01$ & 0.25 & 0.42 \\
\hline $\mathrm{C}_{14: 1}^{140}$ & 14.5 & 11.1 & 8.8 & 15.4 & 12.5 & 11.3 & 0.68 & $<0.01$ & $<0.01$ & 0.26 & 0.48 \\
\hline $\mathrm{C}_{15: 0}$ & 12.9 & 9.4 & 8.1 & 13.8 & 11.3 & 10.7 & 0.79 & 0.02 & $<0.01$ & 0.18 & 0.62 \\
\hline $\mathrm{C}_{16: 0}$ & 304.3 & 255.7 & 240.2 & 337.7 & 304.2 & 311.0 & 12.36 & $<0.01$ & $<0.01$ & 0.10 & 0.33 \\
\hline $\mathrm{C}_{16.1}$ & 16.6 & 15.8 & 17.7 & 15.4 & 15.7 & 17.2 & 0.67 & 0.27 & 0.04 & 0.10 & 0.72 \\
\hline $\mathrm{C}_{17: 0}$ & 6.0 & 7.3 & 8.0 & 6.7 & 8.8 & 9.5 & 0.54 & 0.01 & $<0.01$ & 0.32 & 0.70 \\
\hline $\mathrm{C}_{18: 0}$ & 94.3 & 118.4 & 117.4 & 111.7 & 144.4 & 145.7 & 7.73 & $<0.01$ & $<0.01$ & 0.05 & 0.76 \\
\hline trans $-\mathrm{C}_{18: 1}$ & 14.9 & 27.9 & 44.8 & 13.4 & 21.6 & 34.1 & 3.42 & 0.04 & $<0.01$ & 0.51 & 0.42 \\
\hline cis $-\mathrm{C}_{18: 1,}, n-9$ & 173.8 & 207.9 & 211.9 & 181.5 & 231.6 & 258.6 & 11.79 & 0.01 & $<0.01$ & 0.21 & 0.27 \\
\hline $\mathrm{C}_{18: 2}$ & 27.9 & 22.4 & 16.6 & 30.5 & 26.9 & 23.8 & 1.46 & $<0.01$ & $<0.01$ & 0.99 & 0.31 \\
\hline $\mathrm{C}_{18: 3}$ & 3.2 & 2.6 & 1.9 & 7.0 & 6.0 & 9.7 & 1.77 & $<0.01$ & 0.69 & 0.47 & 0.39 \\
\hline Glycerol & 125.9 & 115.2 & 105.0 & 138.5 & 138.5 & 139.3 & 5.56 & $<0.01$ & 0.09 & 0.94 & 0.18 \\
\hline
\end{tabular}

of $\mathrm{C}_{18: 2}$ in milk fat decreased linearly and that of $\mathrm{C}_{18: 3}$ was unaffected as tallow supplementation increased. The calculated concentration of glycerol in milk fat decreased linearly as dietary tallow increased, which is a consequence of replacement of short- and mediumchain FA with long-chain FA. Our data are similar to the results of others who fed tallow in diets for dairy cows (Clapperton and Steele, 1983; Schauff et al., 1992; Elliott et al., 1993; Grummer et al., 1993).

Yields of short- and medium-chain FA $\left(\mathrm{C}_{6: 0}\right.$ to $\left.\mathrm{C}_{16: 0}\right)$ decreased and those of long-chain FA $\left(\mathrm{C}_{16: 1}\right.$ to $\left.\mathrm{C}_{18: 2}\right)$ increased linearly as tallow supplementation increased (Table 6). Yields of $\mathrm{C}_{4: 0}$ and $\mathrm{C}_{18: 3} \mathrm{FA}$ were unaffected by tallow supplementation. The yield of glycerol tended $(P=0.09)$ to decrease linearly as tallow supplementation increased. Yields of FA generally followed results for changes in milk fat composition (Table 5).

Forage effects. Milk yields were unaffected by dietary forage source (Table 3). Similarly, no differences in milk yield were observed in previous experiments when alfalfa hay or silage diets were compared to corn silage diets or combinations of these forages (Broderick, 1985; Charmley et al., 1993; Smith et al., 1993). Although chemical and digestive characteristics of corn silage and alfalfa silage differ, milk yield by cows might be expected to be similar if diets containing the different forages are properly balanced to equalize provision of energy, metabolizable protein, minerals, and vitamins.

Milk fat content, milk fat yield, and yield of 3.5\% FCM were higher when cows were fed the high alfalfa silage diet than when they were fed the high corn silage diet (Table 3). Milk fat percentages were higher for cows consuming alfalfa-based than for those fed corn silage-based diets in an earlier study (Broderick, 1985). When alfalfa silage replaced a portion of corn silage in diets fed to dairy cows, milk fat content was increased (Smith et al., 1993). Other studies (Broderick, 1985; Charmley et al., 1993) reported no significant differences in milk fat content when cows received diets based on either alfalfa or corn silage.

Content of CP in milk was not affected by dietary forage source; however, CP yield in milk tended $(P=$ 0.07 ) to be higher when cows were fed the high alfalfa silage diet (Table 3). The tendency for an increase in milk CP yield was attributed to nonsignificant increases in milk yields and CP percentages when cows were fed the high alfalfa silage diet. Milk protein content was similar (Broderick, 1985) or higher (Broderick, 1985; Charmley et al., 1993) for cows fed corn silagebased diets than for cows fed diets based on alfalfa hay or silage, possibly reflecting greater ruminal energy availability for cows fed high corn silage diets.

The distribution of $\mathrm{N}$ components in milk, whether expressed as percentages in milk or percentages of total $\mathrm{N}$ or true protein $\mathrm{N}$, did not differ between forage sources (Table 4). Similar to CP, yields of total N $(P=$ $0.07)$, true protein $\mathrm{N}(P=0.06)$, and casein $\mathrm{N}(P=0.08)$ tended to be higher when cows were fed alfalfa silagebased diets.

Milk from cows fed the high alfalfa silage diet had greater contents of $\mathrm{C}_{4: 0}, \mathrm{C}_{8: 0}, \mathrm{C}_{10: 0}, \mathrm{C}_{18: 3}$, and glycerol than milk from cows fed the high corn silage diet (Table 
Table 7. Ruminal characteristics from cows fed diets differing in forage and amount of supplemental fat.

\begin{tabular}{|c|c|c|c|c|c|c|c|c|c|c|c|}
\hline \multirow[b]{3}{*}{ Item } & \multicolumn{6}{|c|}{ Diets } & \multirow[b]{3}{*}{ SEM } & \multicolumn{4}{|c|}{ Significance of effects $(P)$} \\
\hline & \multicolumn{3}{|c|}{ High corn silage } & \multicolumn{3}{|c|}{ High alfalfa silage } & & \multirow[b]{2}{*}{ Forage } & \multicolumn{2}{|c|}{ Fat } & \multirow{2}{*}{$\begin{array}{l}\text { Fat } \times \\
\text { forage }\end{array}$} \\
\hline & $0 \%$ Fat & $2 \%$ Fat & $4 \%$ Fat & $0 \%$ Fat & $2 \%$ Fat & $4 \%$ Fat & & & Linear & Quadratic & \\
\hline $\mathrm{pH}$ & 5.94 & 5.88 & 5.93 & 6.09 & 6.10 & 6.03 & 0.02 & $<0.01$ & 0.17 & 0.67 & 0.07 \\
\hline Total VFA, $\mathrm{m} M$ & 111.6 & 109.6 & 107.2 & 108.3 & 107.6 & 108.4 & 1.7 & 0.32 & 0.21 & 0.84 & 0.38 \\
\hline Acetate, $\mathrm{mol} / 100 \mathrm{~mol}$ & 59.1 & 58.1 & 56.0 & 63.2 & 62.8 & 62.3 & 0.4 & $<0.01$ & $<0.01$ & 0.32 & 0.02 \\
\hline Propionate, mol/100 mol & 26.5 & 28.2 & 30.1 & 22.6 & 23.2 & 24.1 & 0.5 & $<0.01$ & $<0.01$ & 0.81 & 0.11 \\
\hline Valerate, mol/100 mol & 1.7 & 1.6 & 1.7 & 1.5 & 1.6 & 1.6 & 0.1 & 0.13 & 0.41 & 0.97 & 0.10 \\
\hline Isovalerate, $\mathrm{mol} / 100 \mathrm{~mol}$ & 1.9 & 1.7 & 1.9 & 1.7 & 1.7 & 1.6 & 0.1 & $<0.01$ & 0.19 & 0.03 & 0.02 \\
\hline $\mathrm{NH}_{3}-\mathrm{N}, \mathrm{mg} / \mathrm{dl}$ & 22.4 & 25.1 & 22.5 & 22.2 & 21.3 & 19.9 & 1.3 & 0.05 & 0.41 & 0.21 & 0.37 \\
\hline \multicolumn{12}{|l|}{ Ruminal fluid } \\
\hline Volume, L & 81.68 & 74.38 & 76.65 & 82.14 & 81.50 & 84.03 & 4.10 & 0.15 & 0.71 & 0.38 & 0.64 \\
\hline Dilution rate, $\% / \mathrm{h}$ & 9.21 & 8.74 & 9.16 & 10.90 & 10.93 & 11.14 & 0.44 & $<0.01$ & 0.84 & 0.49 & 0.85 \\
\hline Outflow, L/h & 7.65 & 6.50 & 7.01 & 9.22 & 8.96 & 9.49 & 0.76 & $<0.01$ & 0.81 & 0.36 & 0.79 \\
\hline
\end{tabular}

5). Cows fed high corn silage had greater contents of $\mathrm{C}_{16: 1}$ and trans- $\mathrm{C}_{18: 1}$ and tended $(P=0.09)$ to have greater contents of $\mathrm{C}_{14: 1}$ and cis- $\mathrm{C}_{18: 1}$ than cows fed high alfalfa silage. Contents of $\mathrm{C}_{6: 0}, \mathrm{C}_{14: 0}, \mathrm{C}_{15: 0}, \mathrm{C}_{16: 0}, \mathrm{C}_{17: 0}$, $\mathrm{C}_{18: 0}$, and $\mathrm{C}_{18: 2}$ were not affected by dietary forage. Milk FA composition was not altered by dietary forage source in the study of Smith et al. (1993). Differences in yields of FA in milk (Table 6) reflected changes in milk fat composition and milk fat yield (Table 3) between forage sources.

Contents of trans- $\mathrm{C}_{18: 1}$ in milk fat as tallow supplementation increased generally were greater when cows were fed the high corn silage diet, although the tallow by forage interaction did not achieve statistical significance $(P=0.11)$. Increased concentrations of trans $-\mathrm{C}_{18: 1}$ in milk fat are associated with decreased milk fat percentages (Griinari et al., 1998). Although individual trans- $\mathrm{C}_{18: 1}$ isomers and isomers of conjugated linoleic acid were not separated in this experiment, milk fat depression has recently been attributed to ruminal formation of trans-10, cis-12 $\mathrm{C}_{18: 2}$ (Baumgard et al., 2000). Griinari et al. (1998) demonstrated that both an altered ruminal environment, such as that caused by decreased forage and increased NSC, and a dietary source of unsaturated FA must be present to result in milk fat depression. The trans-10, cis- $12 \mathrm{C}_{18: 2}$ isomer may be formed in greater amounts under these conditions (Bauman et al., 2000) and is associated with concurrent increases of trans- $\mathrm{C}_{18: 1}$ isomers. Consequently, it is attractive to speculate that formation of trans-10, cis-12 $\mathrm{C}_{18: 2}$ was greater when cows were fed the high corn silage diet, and increased further as tallow was supplemented to the high corn silage diet, thus explaining the lower milk fat content for cows fed these diets. However,
Onetti et al. (2001) found no increase in trans-10, cis$12 \mathrm{C}_{18: 2}$ in milk fat when tallow was supplemented to a corn silage-based diet, despite the fact that milk fat content was decreased by tallow.

\section{Ruminal Fermentation and Passage Rate Constants}

Tallow effects. The $\mathrm{pH}$ and concentration of total VFA in ruminal fluid (Table 7) were not affected by tallow supplementation. Molar proportions of acetate and butyrate decreased linearly, and the molar proportion of propionate increased linearly, with increasing tallow supplementation. The changes in proportions of propionate and acetate resulted in a linear decrease of the acetate to propionate ratio as tallow supplementation increased. A linear increase in total VFA concentration was reported by Grummer et al. (1993) when 1, 2, or $3 \%$ tallow was supplemented to diets for lactating dairy cows. In nonlactating cows, tallow supplementation increased total VFA when added to diets in which the alfalfa hay was chopped to smaller particle size, and decreased the acetate to propionate ratio regardless of hay particle size (Lewis et al., 1999). Acetate to propionate ratios decreased when tallow was fed in combination with whole soybeans (Schauff et al., 1992) or highoil corn (Elliott et al., 1993). In contrast, total VFA concentrations and acetate to propionate ratios were not affected in other experiments by addition of tallow (Palmquist, 1991; Grummer et al., 1993; Jenkins et al., 1998) or choice white grease (Drackley et al., 1994) to diets of lactating dairy cows. Changes in molar proportions of valerate and isovalerate (Table 7) were small and difficult to interpret. Ruminal $\mathrm{NH}_{3}-\mathrm{N}$ was not affected by tallow supplementation, similar to other reports (Schauff et al., 1992; Elliott et al., 1993). 
Table 8. Apparent total tract digestibilities of nutrient fractions by cows fed diets differing in forage and amount of supplemental fat.

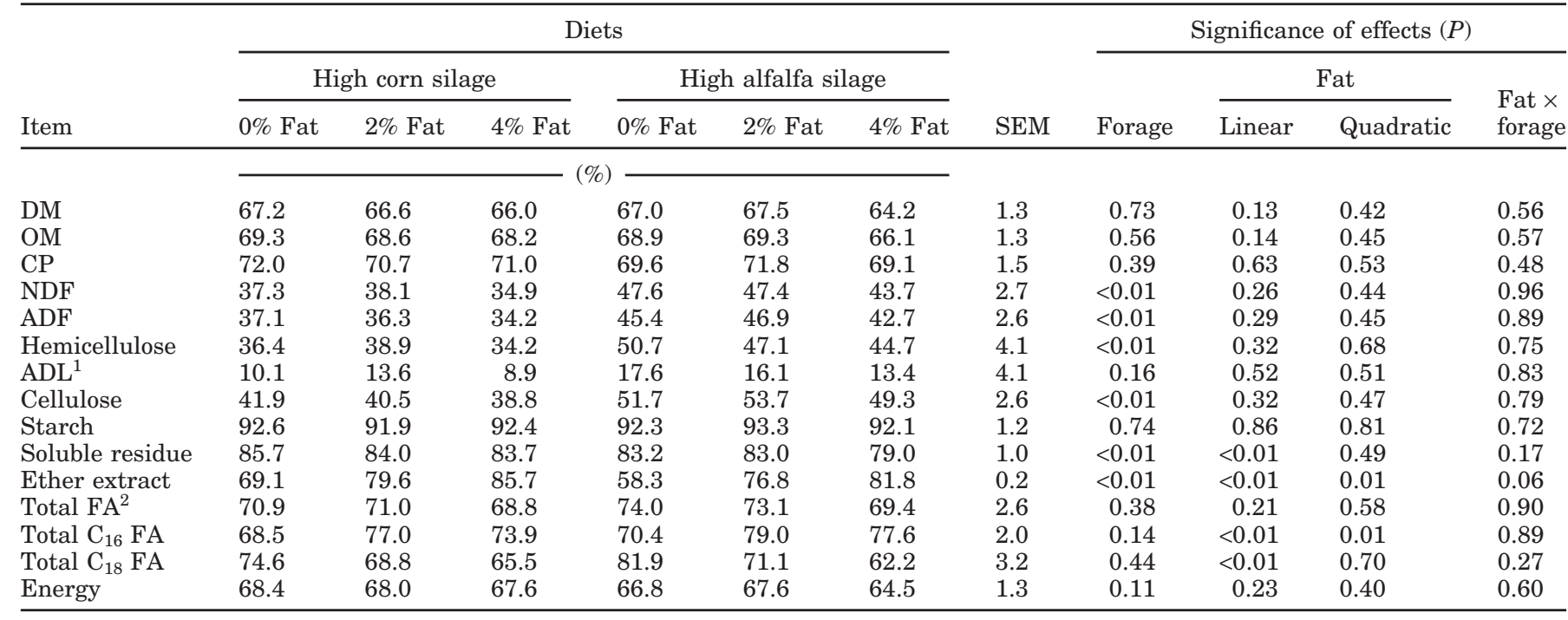

${ }^{1}$ Acid detergent lignin.

${ }^{2}$ Fatty acids.

The interaction of tallow and forage was significant for acetate because the changes in proportion of this VFA were greater as tallow was increased in the high corn silage diet than when tallow was added to the high alfalfa silage diet. Although the interaction of tallow and forage was not significant for propionate $(P=0.11)$, directional changes in acetate and propionate proportions are consistent with the tendency for a greater decrease of milk fat percentage when tallow was added to the high corn silage diet (Table 3). Onetti et al. (2001) also reported decreased acetate to propionate ratios and decreased milk fat content when 2 or $4 \%$ tallow was added to a diet in which corn silage was the only forage. Although the glucogenic theory of milk fat depression has been challenged recently (Gaynor et al., 1995; McGuire et al., 1995) by data showing the involvement of various trans-unsaturated FA (Bauman et al., 2000), a decreased ruminal acetate to propionate ratio is characteristic of the low-fat milk syndrome (Gaynor et al., 1995; Griinari et al., 1998).

Ruminal fluid volume and passage rate constants for liquid and solid fractions were not affected by tallow supplementation. Ruminal passage rates of either solid or liquid phases also were not affected by supplementation of fat to diets for dairy cows in other experiments (Doreau et al., 1991; Ben Salem et al., 1993).

Forage effects. Ruminal $\mathrm{pH}$ was significantly lower when cows were fed high corn silage diets (Table 7). Effects of time after feeding and the interaction of time and forage were significant for ruminal $\mathrm{pH}$ (Figure 1); ruminal $\mathrm{pH}$ decreased after feeding and decreased to a greater extent when cows were fed the high corn silage diet than when they were fed the high alfalfa silage diet. Although cows were fed for ad libitum intake, they consumed a large proportion of their daily intake immediately after feeding, which coincides with the pronounced diurnal pattern of decrease for ruminal $\mathrm{pH}$ (Figure 1). The greater decreases of ruminal $\mathrm{pH}$ after feeding high corn silage diets may be attributable to rapid fermentation of the readily available starch in corn silage, the smaller particle size (not measured) that likely stimulated less rumination (Allen and Mertens, 1988), and to the decreased buffering capacity of corn silage (Crawford et al., 1983). Alternately, effective fiber in the diet may have been insufficient even though minimum recommendations for forage NDF (NRC, 1989) were exceeded. Forage particle size distribution was not measured, but by visual appraisal we would characterize the particle length of the corn silage as smaller than desirable. Regardless of cause, the lower ruminal $\mathrm{pH}$ may have favored the increased accumulation of FA with trans double bonds in the rumen when cows were fed the high corn silage diet and the high corn silage diets supplemented with tallow (Kalscheur et al., 1997; Griinari et al., 1998; Bauman et al., 2000). These changes may explain the increases of milk trans$\mathrm{C}_{18: 1}$ (Table 6) and could be a factor in the lower milk fat percent for cows fed these diets (Table 3).

The concentration of total VFA and the molar proportion of butyrate (Table 7) were unaffected by dietary forage source. Consistent with the lower ruminal $\mathrm{pH}$, the molar proportion of acetate was lower, and that of propionate was higher, when cows were fed the high corn silage diet. These changes caused a significant 


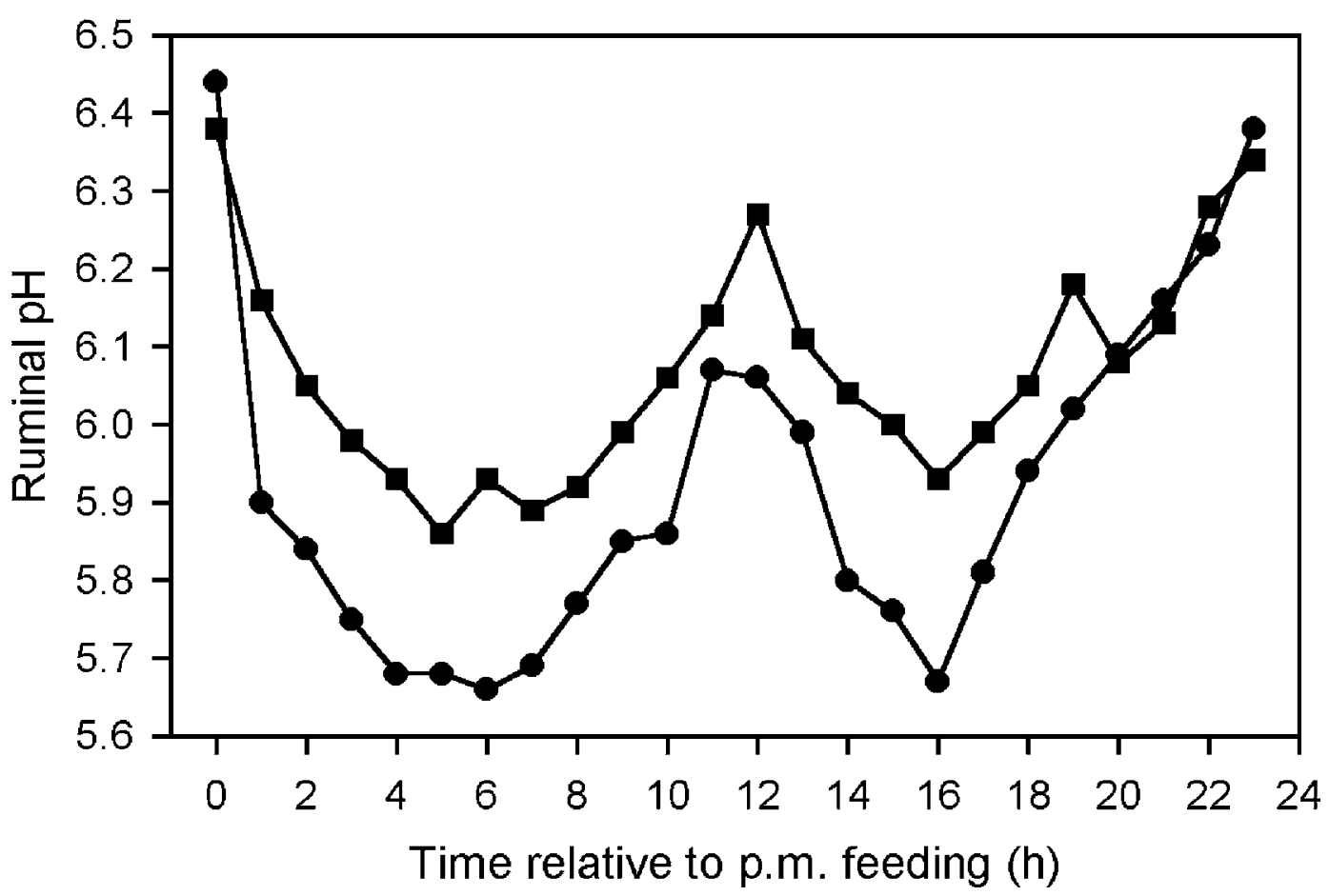

Figure 1. Ruminal pH in cows fed high corn silage (circles) or high alfalfa silage (squares) diets. Values are means for main effects of forage source. Cows were fed for ad libitum intake; the TMR was delivered immediately after samples at 0 and $12 \mathrm{~h}$. The interaction of forage source $\times$ time relative to feeding was significant $(P<0.01)$; effects of tallow amount $\times$ time $(P=0.83)$ and forage $\times$ tallow amount $\times$ time $(P=0.99)$ were not significant. The pooled SEM $=0.17$.

decrease in the acetate to propionate ratio when cows were fed the high corn silage diet. Such ruminal changes are typical for diets that provide different amounts of fermentable fiber and starch (Grum et al., 1996; Griinari et al., 1998). The molar proportion of isovalerate was higher when cows were fed high corn silage diets, perhaps indicating differences in ruminal protein degradation between forage types.

Similar to our data, ruminal $\mathrm{pH}$ was lower (Broderick, 1985) for cows fed diets based on corn silage than for those fed alfalfa-based diets. The molar proportion of acetate was lower (Broderick, 1985; Charmley et al., 1993) and that of propionate was higher (Broderick, 1985) for cows fed diets based on corn silage. Cows consuming corn silage-based diets had a higher molar proportion of butyrate (Broderick, 1985; Charmley et al., 1993) and lower valerate and isovalerate (Broderick, 1985) than cows consuming alfalfa-based diets.

The concentration of ruminal $\mathrm{NH}_{3}-\mathrm{N}$ was higher when cows were fed corn silage-based diets. Calculated contents of dietary RUP (34.1\% vs. $33.6 \%$ ) and RDP (60.5\% and $62.0 \%)$ were similar for high corn silage and high alfalfa silage diets, respectively. The greater concentration of starch (Table 2), which provides energy to rumen microbes, may have led to greater microbial growth; increased microbial growth with decreased ru- minal liquid dilution rates (Table 7) may have led to greater microbial lysis and $\mathrm{N}$ recycling in the rumen. Alternately, because the greater dietary concentrations of starch led to lower ruminal $\mathrm{pH}$ and lower liquid dilution rate, microbial growth efficiency may have decreased.

Ruminal fluid dilution rate and outflow were higher for cows consuming high alfalfa silage diets. Ruminal fluid volume and particulate passage rate were similar between dietary forage sources. Increased dilution rate is consistent with greater effective fiber in high alfalfa silage diets, which would lead to greater rumination (Allen and Mertens, 1988), increased saliva flow and buffering (Allen, 1997), and maintenance of greater ruminal $\mathrm{pH}$ after feeding (Figure 1). Such differences have been observed previously between high and low forage diets (Allen and Mertens, 1988).

\section{Total Tract Apparent Nutrient Digestibilities}

Tallow effects. The apparent digestibility coefficients for DM, OM, CP, NDF, ADF, hemicellulose, ADL, cellulose, starch, and energy did not differ $(P>0.10)$ among amounts of tallow supplementation (Table 8). Digestibilities of soluble residue (likely containing a high content of pectins and sugars) decreased linearly 
with increasing tallow supplementation, perhaps indicating that tallow interfered with fermentation of these substances. In other experiments, feeding tallow (Elliott et al., 1993) or choice white grease (Drackley et al., 1994) had no detrimental effects on apparent nutrient digestibilities compared with diets without supplemental fat. However, in diets containing $10 \%$ whole soybeans, digestibilities of $\mathrm{DM}, \mathrm{OM}$, and $\mathrm{CP}$ were decreased by supplemental tallow compared with control diets (Schauff et al., 1992). Addition of 5\% tallow to a diet based on chopped alfalfa hay and corn silage had no effect on total tract digestibilities of DM or NDF, but decreased in situ digestibility of NDF (Lewis et al., 1999).

Although measurement of total FA more accurately reflects the nutritional value of dietary lipid (Sukhija and Palmquist, 1988), EE was measured to provide additional information about relationships between the two measurements. Digestion coefficients for EE increased quadratically with increasing tallow supplementation (Table 8); differences were greater between 0 and $2 \%$ tallow than between 2 and $4 \%$ tallow. Digestibility of EE often increases when dietary fat is supplemented (Palmquist, 1991) because the supplemental fat dilutes the effects of endogenous lipid secretions. A tendency $(P=0.06)$ for a tallow by forage interaction for digestibility of $\mathrm{EE}$ was observed, and that may be attributed to the higher content of non-FA lipid in EE from high alfalfa silage diets compared with high corn silage diets. Smith et al. (1993) reported greater EE digestibility when tallow was supplemented to diets containing both corn silage and alfalfa silage than when tallow was added to diets containing corn silage only.

Apparent digestibility of total FA was not affected by tallow supplementation (Table 8). Apparent digestibility of total $\mathrm{C}_{16} \mathrm{FA}$ was increased quadratically by increasing tallow supplementation, with the greatest digestibility for diets containing $2 \%$ tallow. Digestibility of total $\mathrm{C}_{18}$ FA decreased linearly with increasing tallow supplementation. Our results for apparent digestibility of total FA agree well with those of others (Palmquist, 1991; Weisbjerg et al., 1992), but contrast with those from previous studies in our laboratory, in which digestibilities of total FA decreased when as much as $4 \%$ tallow was added to a diet containing additional fat from whole soybeans (Schauff et al., 1992) or when as much as 5\% tallow was added to a diet containing highoil corn (Elliott et al., 1993).

To obtain an estimate of true digestibility of FA, total FA absorbed was regressed on total FA intake (Figure 2 ). As indicated by the coefficient of determination $\left(R^{2}\right)$, $91 \%$ of the variation in amount of FA digested was explained by FA intake. Addition of a quadratic term did not account for any additional variance. As esti- mated by the linear regression coefficient (Palmquist, 1991) the true digestibility of FA in the total diets was $79 \%$. Regressions were linear when conducted within forage types and estimates of digestibility did not differ $(81 \pm 5.6 \%$ vs. $77 \pm 7.0 \%$ for corn silage and alfalfa silage diets). The intercept indicates a rate of endogenous secretion of FA of $66 \mathrm{~g} / \mathrm{d}$, which agrees well with data from Palmquist (1991) but is slightly higher than the value $(34 \mathrm{~g} / \mathrm{d})$ predicted by the model of Weisbjerg et al. (1992). Our data show no decrease of FA absorption at high intakes as reported by others (Palmquist, 1991; Weisbjerg et al., 1992), although greater dietary concentrations of fat were fed in those experiments.

Digestibilities of FA in tallow were somewhat higher than those in previous experiments from our laboratory (Schauff et al., 1992; Elliott et al., 1993). Estimated by the difference technique, the true digestibility of tallow FA was 75.4 and $68.9 \%$ when fed at 2 and $4 \%$ of the DM in the high corn silage diet, and 70.3 and $65.8 \%$ when fed at 2 and $4 \%$ of the high alfalfa silage diet, respectively. The NRC (2001) assigned a FA digestibility of $68 \%$ for tallow in cows at maintenance energy intake, which would equate to approximately $64 \%$ digestibility for cows at about $2.5 \times$ maintenance intake as in our study. Use of the difference method estimates digestibility of FA in the supplemental fat source itself while assuming that digestibility of basal FA does not change due to fat addition. In contrast, use of the coefficients from the regressions of total FA absorbed on total FA intake accounts for the changes in digestibility of total FA in the diet as a result of supplemental fat addition (see Palmquist, 1991, for discussion).

Forage effects. Digestibilities of DM, OM, CP, ADL, and starch were not affected by dietary forage source (Table 8). Digestibilities of NDF, ADF, hemicellulose, and cellulose were greater for the high alfalfa silage diet than for the high corn silage diet. Digestibility of soluble residue was greater when cows were fed high corn silage, perhaps reflecting greater digestibility of pectins and sugars from corn silage. In previous experiments, digestibilities of DM and NDF by lactating dairy cows were not different among diets based on corn silage and either alfalfa hay or silage (Broderick, 1985; Charmley et al., 1993). Broderick (1985) observed lower digestibility of DM when cows were fed diets based on alfalfa hay or silage than when they were fed diets based on corn silage. Digestibilities of DM and OM were higher, and those of NDF, ADF, and hemicellulose were unaffected, for cows fed corn silage compared to those fed grass hay (Ben Salem et al., 1993). When alfalfa silage replaced a portion of corn silage in diets fed to dairy cows, DM digestibility was not different (Smith et al., 1993). 


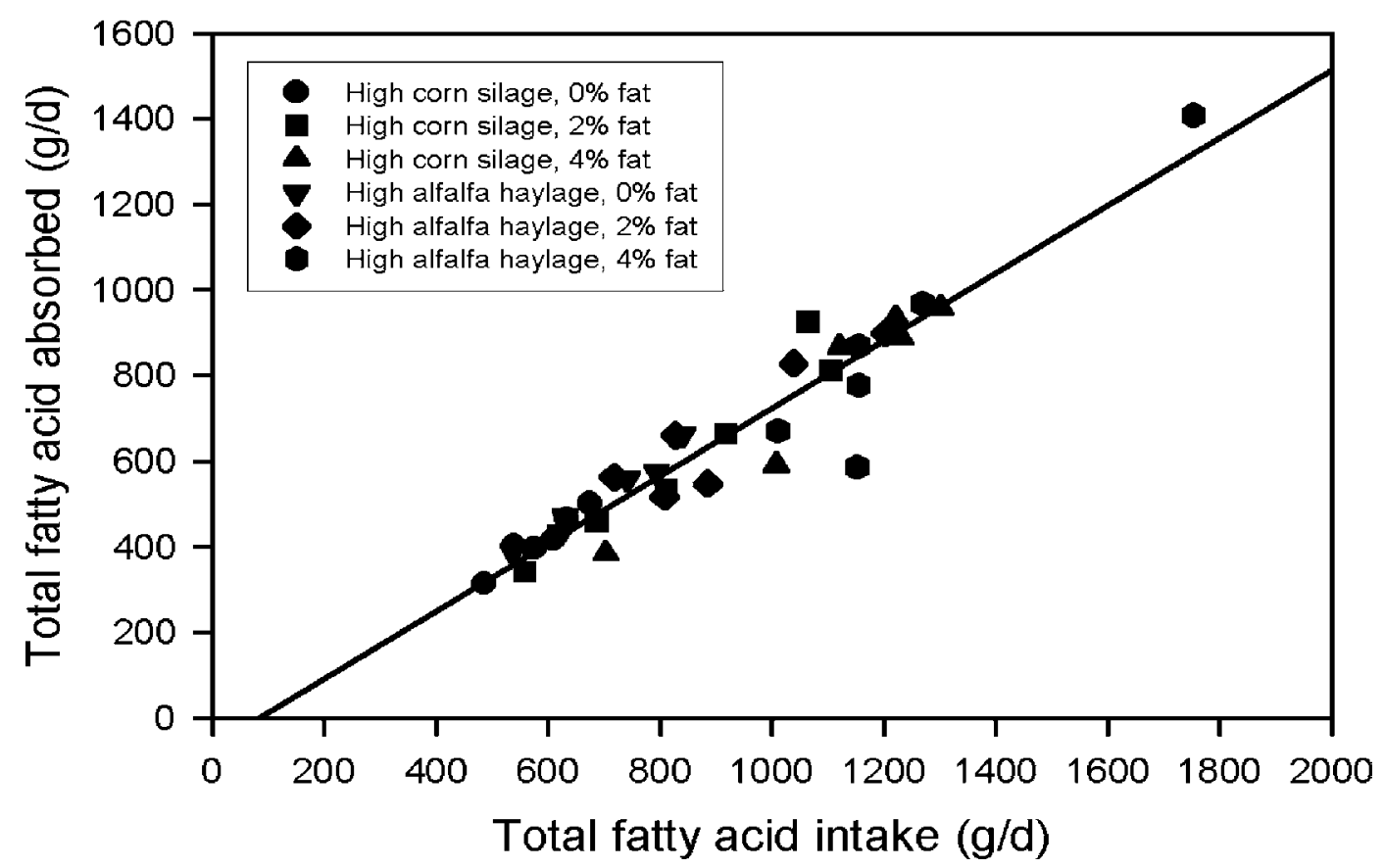

Figure 2. The effects of intake of total fatty acids on the amount of fatty acids absorbed. The plotted line shows the regression: $\mathrm{y}=0.79 \mathrm{x}$ $\pm 0.04-66 \pm 0.4\left(R^{2}=0.91\right)$.

Diets with a greater content of starch or non-fiber carbohydrates may decrease fiber digestibilities, which is associated with decreased ruminal $\mathrm{pH}$, decreased ruminal fluid dilution rate, and consequent changes in microbial populations (Allen and Mertens, 1988). Fiber digestibility is decreased when ruminal $\mathrm{pH}$ drops below 6 for extended periods of time (Allen, 1997). In our experiment, dietary contents of starch and soluble residue were greater for cows fed the high corn silage diets; although total tract starch digestibility did not differ, larger quantities of starch and soluble residue (likely pectins and sugars) probably were fermented in the rumen when cows were the high corn silage diets. Cows fed high corn silage diets had a ruminal $\mathrm{pH}<6$ for about $15 \mathrm{~h}$ (Figure 1) whereas cows fed high alfalfa silage had ruminal $\mathrm{pH}<6$ for about $7 \mathrm{~h}$. Low ruminal $\mathrm{pH}$ may have contributed to the lower digestibilities of NDF, $\mathrm{ADF}$, and cellulose when cows were fed the high corn silage diet. In other experiments, lower liquid dilution rates (Crawford et al., 1980; Rogers et al., 1982) and solid passage rates (Crawford et al., 1980) were associated with decreased digestibilities of $\mathrm{DM}, \mathrm{NDF}, \mathrm{ADF}$, and cellulose and lower ruminal $\mathrm{pH}$. The lower liquid dilution rate when cows were fed the high corn silage diet in our study coincides with lower fiber digestibilities and lower ruminal $\mathrm{pH}$. However, Broderick (1985) found no differences in ruminal liquid volume and turnover rate between cows fed corn silage or alfalfa based diets.
Digestibility of EE was greater when cows were fed high corn silage diets, perhaps because of the greater contents of poorly digested pigments and waxes in alfalfa (Sukhija and Palmquist, 1988). Digestibilities of total, total $\mathrm{C}_{16}$, and total $\mathrm{C}_{18} \mathrm{FA}$ were not affected by dietary forage source. Differences in interpretation of responses of EE and FA digestibilities among diets highlights the desirability of using FA rather than EE.

\section{Energy Utilization}

Tallow effects. Intake energy $(P=0.10)$ and digestible energy $(P=0.07)$ tended to decrease linearly with increased tallow supplementation (Table 9 ) because the linear decrease in DMI as tallow supplementation increased was greater than could be compensated by the greater energy density of the tallow-supplemented diets. Calculated gaseous energy decreased linearly as tallow supplementation increased because smaller amounts of cellulose, hemicellulose, and soluble residue were digested. Other energy variables were not affected significantly by supplementation of tallow. As percentages of intake energy, gaseous energy decreased linearly and milk energy increased linearly with increasing tallow supplementation. Other values as percentages of intake energy were unaffected by tallow supplementation.

Improved energy utilization is one of the goals of adding tallow to diets for lactating dairy cows. The 
Table 9. Utilization of dietary energy by cows fed diets differing in forage and amount of supplemental fat.

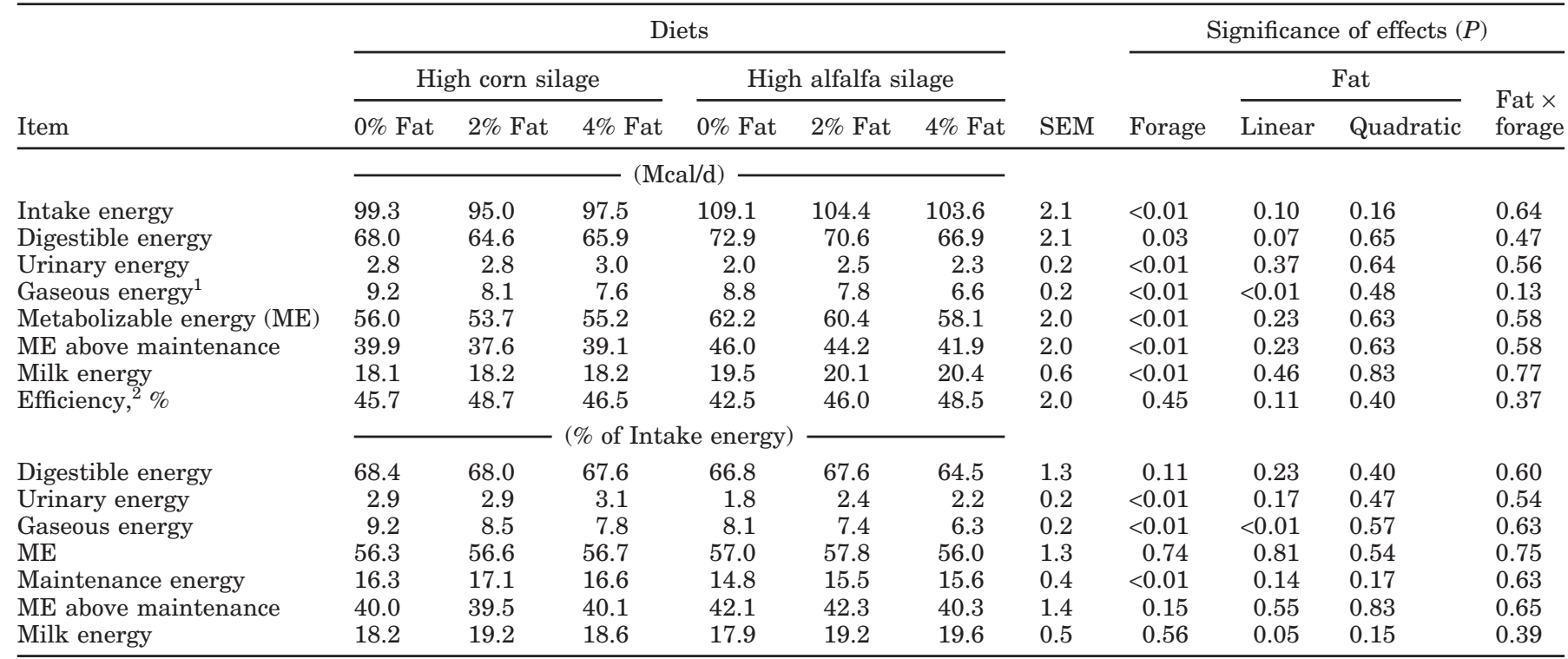

${ }^{1}$ Calculated from regression equation of Moe and Tyrrell (1979).

${ }^{2}$ Milk energy/ME above maintenance.

stepwise increases in means for efficiency of milk production as tallow supplementation increased (Table 9) did not achieve statistical significance $(P=0.11)$. In previous experiments using similar methodology, efficiency of milk production was not improved significantly by fat supplementation (Schauff et al., 1992; Elliott et al., 1993; Drackley and Elliott, 1993). Improved efficiency of energy utilization from the small amounts of tallow added would increase efficiency of total dietary energy use by only one to two percentage units, which is difficult to detect statistically using the current experimental design and methodology.

Forage effects. Gross energy content of diets was similar between forages, but greater DMI caused greater energy intakes for cows fed the high alfalfa silage diet (Table 9). Cows fed high alfalfa silage had higher intake energy, digestible energy, and metabolizable energy than cows fed high corn silage. Means for urinary and gaseous energy were higher when cows were fed high corn silage diets than when cows were fed high alfalfa silage diets. Metabolizable energy above maintenance and milk energy were higher for high alfalfa silage diets than for high corn silage diets. Dietary forage source had no effect on efficiency of milk production. Digestible, urinary, gaseous, and maintenance energies were a greater percentage of intake energy when cows were fed the high corn silage diet. Metabolizable energy and milk energy were not significantly different between dietary forage sources.

\section{Nitrogen Utilization}

Tallow effects. Intake $\mathrm{N}$ and absorbed $\mathrm{N}$ (Table 10) decreased linearly with increased tallow supplementation because of the linear decrease in DMI. No other measures of $\mathrm{N}$ balance were affected by tallow supplementation. An increase (Drackley and Elliott, 1993), decrease (Schauff et al., 1992), or no effect (Elliott et al., 1993) on absorbed $\mathrm{N}$ have been reported when diets were supplemented with fats.

Forage effects. Intake $\mathrm{N}$ and fecal $\mathrm{N}$ were higher when cows were fed high alfalfa silage diets than when they were fed high corn silage diets (Table 10). These differences were caused by greater DMI and a slightly higher dietary CP content for the alfalfa silage-based diets. Urine $\mathrm{N}$ was unaffected by forage source. Cows fed the high alfalfa silage diet absorbed more dietary $\mathrm{N}$ than those fed the high corn silage diet. Combined with the tendency for greater milk $\mathrm{N}$, higher absorbed $\mathrm{N}$ resulted in higher values for retained $\mathrm{N}$ and productive $\mathrm{N}$ when cows were fed the high alfalfa silage diet.

Milk $\mathrm{N}$ represented a greater proportion of intake $\mathrm{N}$ when cows were fed the high corn silage diet than when they were fed high alfalfa silage. As percentages of intake $\mathrm{N}$, urine $\mathrm{N}$ tended $(P=0.06)$ to be higher and retained $\mathrm{N}$ tended $(P=0.09)$ to be lower when cows were fed corn silage-based diets. Fecal $\mathrm{N}$ and productive $\mathrm{N}$ as percentages of intake $\mathrm{N}$ were unaffected by dietary forage source. As a percentage of absorbed $\mathrm{N}$, urine $\mathrm{N}$ tended $(P=0.10)$ to be higher and retained $(P=0.08)$ 
Table 10. Utilization of dietary $\mathrm{N}$ by cows fed diets differing in forage and amount of supplemental fat.

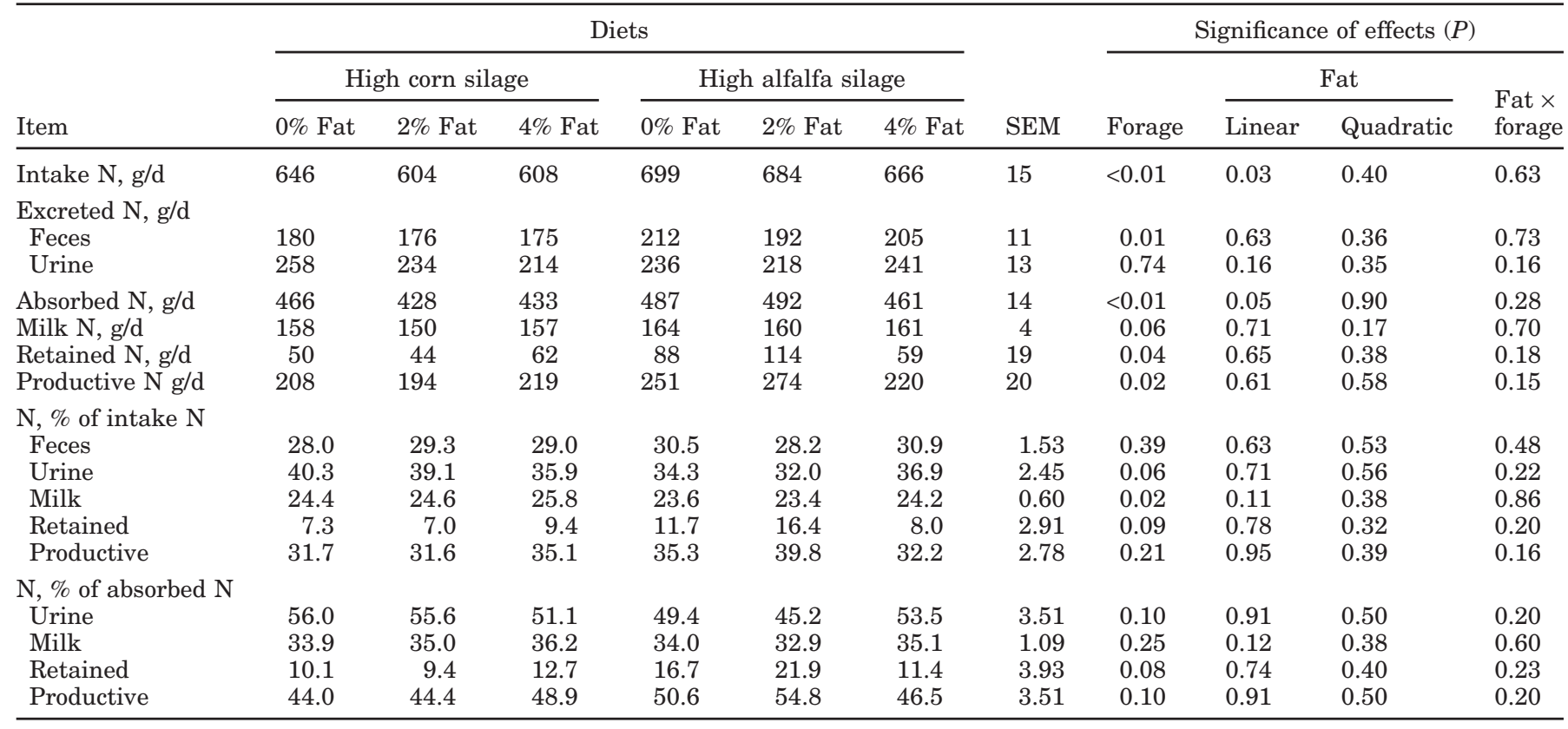

and productive $\mathrm{N}(P=0.10)$ tended to be lower when high corn silage diets were fed. Milk $\mathrm{N}$ as a percentage of absorbed $\mathrm{N}$ was not affected by forage source.

Values for $\mathrm{N}$ retention (Table 10) were high and would equate to 275 to $712 \mathrm{~g}$ of protein retained. If body tissue contains about $20 \%$ protein, such values would represent BW gains of up to $3.2 \mathrm{~kg} / \mathrm{d}$. Consequently, $\mathrm{N}$ retention likely was overestimated in this study. Balance trials tend to overestimate $\mathrm{N}$ intake and underestimate $\mathrm{N}$ excretion (MacRae et al., 1993).

\section{Blood Metabolites}

Tallow effects. Means for concentrations of blood metabolites in plasma before and after feeding are summarized in Table 11. Concentrations of glucose, urea, and BHBA were not affected by tallow supplementation. These data agree with previous research showing that concentrations of BHBA and glucose are not affected when supplemental fat is fed to lactating dairy cows (Grummer and Carroll, 1991). Concentrations of NEFA and cholesterol increased linearly with increased tallow supplementation both before and after feeding. Generally, plasma concentrations of NEFA and cholesterol increase with fat supplementation (Grummer and Carroll, 1991; Schauff et al., 1992; Elliott et al., 1993).

Forage effects. Concentrations of glucose at 0 and $3 \mathrm{~h}$ relative to feeding were unaffected by dietary forage source (Table 11). Concentrations of urea in plasma tended $(P<0.06)$ to be lower before feeding when cows were fed the high alfalfa silage diet; however, no forage effect was detected at $3 \mathrm{~h}$ after feeding. The concentration of NEFA was unaffected by dietary forage source before feeding, but was significantly higher $3 \mathrm{~h}$ after feeding for cows fed the high alfalfa silage diet. Plasma concentrations of cholesterol were higher at both times when cows were fed the high alfalfa silage diets. Concentrations of BHBA did not differ between forage sources pre-feeding but were somewhat higher $(P=$ 0.12 ) at $3 \mathrm{~h}$ after feeding for cows fed the high alfalfa silage diet. Increased concentrations of NEFA and cholesterol in plasma may be attributed to greater FA intakes when cows were fed the high alfalfa silage diet.

\section{CONCLUSIONS}

Diets based on different forage sources had significant effects on metabolism and production of dairy cows. Cows fed high alfalfa silage diets had greater DMI, which caused greater intakes of energy and N. Cows fed the high alfalfa silage diet had higher milk fat percentages and yields of $3.5 \% \mathrm{FCM}$ and tended to have greater milk CP yield than cows fed high corn silage; however, milk yield was similar between forage sources. Ruminal fermentation was more favorable in cows fed alfalfa silage-based diets, because these diets resulted in greater rates of ruminal fluid dilution and outflow and maintained ruminal $\mathrm{pH}>6$ for longer periods of time. As a result, total tract digestibility of fiber fractions was greater for high alfalfa silage diets than for high corn silage diets. 
Table 11. Concentrations of metabolites in plasma from cows fed diets differing in forage and amount of supplemental fat.

\begin{tabular}{|c|c|c|c|c|c|c|c|c|c|c|c|}
\hline \multirow[b]{3}{*}{ Item } & \multicolumn{6}{|c|}{ Diets } & \multicolumn{5}{|c|}{ Significance of effects $(P)$} \\
\hline & \multicolumn{3}{|c|}{ High corn silage } & \multicolumn{3}{|c|}{ High alfalfa silage } & \multirow[b]{2}{*}{ SEM } & \multirow[b]{2}{*}{ Forage } & \multicolumn{2}{|c|}{ Fat } & \multirow{2}{*}{$\begin{array}{l}\text { Fat } \times \\
\text { forage }\end{array}$} \\
\hline & $0 \%$ Fat & $2 \%$ Fat & $4 \%$ Fat & $0 \%$ Fat & $2 \%$ Fat & $4 \%$ Fat & & & Linear & Quadratic & \\
\hline \multicolumn{12}{|c|}{ Glucose, mg/dl } \\
\hline $0 \mathrm{~h}^{1}$ & 75.4 & 74.2 & 75.6 & 77.6 & 74.5 & 73.0 & 1.85 & 0.99 & 0.25 & 0.51 & 0.45 \\
\hline $3 \mathrm{~h}$ & 66.2 & 66.6 & 67.38 & 66.9 & 66.0 & 70.4 & 2.11 & 0.55 & 0.29 & 0.47 & 0.68 \\
\hline \multicolumn{12}{|c|}{ Urea, mg/dl } \\
\hline $0 \mathrm{~h}$ & 16.9 & 16.1 & 16.8 & 16.1 & 15.9 & 15.3 & 0.52 & 0.06 & 0.44 & 0.54 & 0.44 \\
\hline $3 \mathrm{~h}$ & 20.7 & 19.6 & 20.2 & 20.2 & 20.6 & 19.9 & 0.59 & 0.90 & 0.51 & 0.77 & 0.41 \\
\hline \multicolumn{12}{|c|}{ NEFA, $\mu \mathrm{eq} / \mathrm{L}$} \\
\hline $0 \mathrm{~h}$ & 115.6 & 128.4 & 172.0 & 113.8 & 159.4 & 167.0 & 12.13 & 0.42 & $<0.01$ & 0.87 & 0.28 \\
\hline $3 \mathrm{~h}$ & 99.7 & 117.7 & 138.4 & 105.9 & 151.9 & 163.1 & 9.66 & 0.01 & 0.01 & 0.35 & 0.36 \\
\hline \multicolumn{12}{|c|}{ Cholesterol, mg/dl } \\
\hline $0 \mathrm{~h}$ & 167.4 & 203.7 & 213.4 & 204.0 & 253.5 & 251.6 & 13.42 & $<0.01$ & $<0.01$ & 0.11 & 0.87 \\
\hline $3 \mathrm{~h}$ & 189.3 & 191.2 & 225.2 & 226.3 & 238.7 & 254.5 & 13.83 & $<0.01$ & 0.03 & 0.47 & 0.80 \\
\hline \multicolumn{12}{|c|}{ BHBA, mg/dl } \\
\hline $0 \mathrm{~h}$ & 6.2 & 6.2 & 6.6 & 6.5 & 6.7 & 6.2 & 0.51 & 0.76 & 0.87 & 0.88 & 0.60 \\
\hline $3 \mathrm{~h}$ & 7.9 & 7.1 & 7.2 & 7.9 & 8.4 & 8.2 & 0.57 & 0.12 & 0.72 & 0.92 & 0.56 \\
\hline
\end{tabular}

${ }^{1}$ Relative to feeding.

The effects of supplementing tallow to corn silage or alfalfa silage diets were minimal. Intakes of DM were decreased linearly and intakes of FA were linearly increased with tallow supplementation; however, milk yield and composition were not altered significantly. The addition of tallow to diets altered ruminal fermentation by decreasing the molar proportion of acetate, increasing the molar proportion of propionate, and decreasing the acetate to propionate ratio; the effect on acetate was greater when tallow was added to the high corn silage diet. However, alterations in ruminal fermentation due to tallow supplementation did not negatively affect total tract digestibilities of DM, CP, or fiber fractions. The digestibility of total FA was not affected by the source of forage in the diet and did not decrease significantly with greater tallow intakes. Utilization of energy and $\mathrm{N}$ was not improved with tallow supplementation because of tallow-related decreases in DMI.

In general, few interactions of dietary tallow and forage source were detected. However, tendencies for decreased milk fat percentage, alterations of ruminal fermentation, and increases in milk fat content of trans$\mathrm{C}_{18: 1}$ when high corn silage diets were supplemented with dietary tallow indicate that tallow had more negative effects on ruminal fermentation in high corn silage diets.

\section{REFERENCES}

Allen, M. S. 1997. Relationship between fermentation acid production in the rumen and the requirement for physically effective fiber. J. Dairy Sci. 80:1447-1462.

Allen, M. S., and D. R. Mertens. 1988. Evaluating constraints on fiber digestion by rumen microbes. J. Nutr. 118:261-270.
Association of Official Analytical Chemists. 1984. Official Methods of Analysis. 14th ed. AOAC, Arlington, VA.

Bauman, D. E., L. H. Baumgard, B. A. Corl, and J. M. Griinari. 2000. Biosynthesis of conjugated linoleic acid in ruminants. Proc. Am. Soc. Anim. Soc., 1999. Available at: http://www.asas.org/jas/symposia/proceedings/0937.pdf. Accessed August 28, 2001.

Baumgard, L. H., B. A. Corl, D. A. Dwyer, A. Saebo, and D. E. Bauman. 2000. Identification of the conjugated linoleic acid isomer that inhibits milk fat synthesis. Am. J. Physiol. 278:R179-R184.

Ben Salem, H., R. Krzeminski, A. Ferlay, and M. Doreau. 1993. Effect of lipid supply on in vivo digestion in cows: comparison of hay and corn silage diets. Can. J. Anim. Sci. 73:547-557.

Broderick, G. A. 1985. Alfalfa silage or hay versus corn silage as the sole forage source for lactating dairy cows. J. Dairy Sci. 68:3262-3271.

Chaney, A., and E. P. Marbach. 1962. Modified reagents for determination of urea and ammonia. Clin. Chem. 8:130-132.

Charmley, E., P. H. Robinson, and R. E. McQueen. 1993. Corn or alfalfa as the forage source in predominately silage diets for latelactation dairy cows. Can. J. Anim. Sci. 73:67-77.

Clapperton, J. L., and W. Steele. 1983. Effects of concentrates with beef tallow on food intake and milk production of cows fed grass silage. J. Dairy Sci. 66:1032-1038.

Cochran, W. G., and G. M. Cox. 1957. Experimental Designs. 2nd ed. John Wiley and Sons, New York, NY.

Crawford, R. J., Jr., W. H. Hoover, and L. L. Junkins. 1980. Effects of solids and liquid flows on fermentation in continuous culture. II. Nitrogen partition and efficiency of microbial synthesis. J. Anim. Sci. 51:986-995.

Crawford, R. J., Jr., B. J. Shriver, G. A. Varga, and W. H. Hoover. 1983. Buffer requirements for maintenance of $\mathrm{pH}$ during fermentation of individual feeds in continuous culture. J. Dairy Sci. 66:1881-1890.

DePeters, E. J., S. J. Taylor, and R. L. Baldwin. 1989. Effect of dietary fat in isocaloric rations on the nitrogen content of milk from Holstein cows. J. Dairy Sci. 72:2949-2957.

Doreau, M., F. Legay, and D. Bauchart. 1991. Effect of source and level of supplemental fat on total and ruminal organic matter and nitrogen digestion in dairy cows. J. Dairy Sci. 74:2233-2242.

Drackley, J. K., and J. P. Elliott. 1993. Milk composition, ruminal characteristics, and nutrient utilization in dairy cows fed partially hydrogenated tallow. J. Dairy Sci. 76:183-196. 
Drackley, J. K., D. E. Grum, G. C. McCoy, and T. H. Klusmeyer. 1994. Comparison of three methods for incorporation of liquid fat into diets for lactating dairy cows. J. Dairy Sci. 77:1386-1398.

Elliott, J. P., J. K. Drackley, D. J. Schauff, and E. H. Jaster. 1993. Diets containing high oil corn and tallow for dairy cows during early lactation. J. Dairy Sci. 76:775-789.

Ellis, E. C., and C. Lascano. 1982. Solute and particulate flow markers. Pages 37-56 in Protein requirements for Cattle: Symposium. F. N. Owens, ed. Oklahoma State Univ. Press, Stillwater.

Fellner, V., M. F. Weiss, A. T. Belo, R. L. Belyea, F. A. Martz, and A. H. Orma. 1988. Urine cup for collection from cows. J. Dairy Sci. 71:2250-2255.

Fruend, R. J., and R. C. Littell. 1981. SAS for Linear Models: A Guide to the ANOVA and GLM Procedures. SAS Inst. Inc., Cary, NC.

Gaynor, P. J., D. R. Waldo, A. V. Capuco, R. A. Erdman, L. W. Douglass, and B. B. Teter. 1995. Milk fat depression, the glucogenic theory, and trans-C18:1 fatty acids. J. Dairy Sci. 78:2008-2015.

Griinari, J. M., D. A. Dwyer, M. A. McGuire, D. E. Bauman, D. L. Palmquist, and K. V. V. Nurmela. 1998. Trans-octadecenoic acids and milk fat depression in lactating dairy cows. J. Dairy Sci. 81:1251-1261

Grum, D. E., J. K. Drackley, L. R. Hansen, and J. D. Cremin, Jr. 1996. Production, digestion, and hepatic lipid metabolism of dairy cows fed increased energy from fat or concentrate. J. Dairy Sci. 79:1836-1849.

Grummer, R. R., and D. J. Carroll. 1991. Effects of dietary fat on metabolic disorders and reproductive performance of dairy cattle. J. Dairy Sci. 69:3838-3852.

Grummer, R. R., M. L. Luck, and J. A. Barmore. 1993. Rumen fermentation and lactational performance of cows fed roasted soybeans and tallow. J. Dairy Sci. 76:2674-2681.

International Dairy Federation. 1964. Determination of casein content of milk. Int. Dairy Fed. Stand. 29. IDF, Brussels, Belgium.

Jenkins, T. C., J. A. Bertrand, and W. C. Bridges, Jr. 1998. Interactions of tallow and hay particle size on yield and composition of milk from lactating Holstein cows. J. Dairy Sci. 81:1396-1402.

Johnson, M. M., and J. P. Peters. 1993. Technical note: an improved method to quantify nonesterified fatty acids in bovine plasma. J. Anim. Sci. 71:753-756.

Kalscheur, K. F., B. B. Teter, L. S. Piperova, and R. A. Erdman. 1997. Effect of dietary forage concentration and buffer addition on duodenal flow of trans- $\mathrm{C}_{18.1}$ fatty acids and milk fat production in dairy cows. J. Dairy Sci. 80:2104-2114.

Kartchner, R. J., and B. Theurer. 1981. Comparison of hydrolysis methods used in feed, digesta, and fecal starch analysis. J. Agric. Food Chem. 29:8-11.

Klusmeyer, T. H., J. H. Clark, J. L. Vicini, M. R. Murphy, and G. C. Fahey, Jr. 1987. Effects of feeding or infusing ammonium salts of volatile fatty acids on ruminal fermentation, plasma characteristics, and milk production. J. Dairy Sci. 70:50-63.

Lewis, W. D., J. A. Bertrand, and T. C. Jenkins. 1999. Interaction of tallow and hay particle size on ruminal parameters. J. Dairy Sci. 82:1532-1537.
MacRae, J. C., A. Walker, D. Brown, and G. E. Lobley. 1993. Accretion of total protein and individual amino acids by organs and tissues of growing lambs and the ability of nitrogen balance techniques to quantitate protein retention. Anim. Prod. 57:237-245.

McGuire, M. A., J. M. Griinari, D. A. Dwyer, and D. E. Bauman. 1995. Role of insulin in the regulation of mammary synthesis of fat and protein. J. Dairy Sci. 78:816-824.

Moe, P. W., and H. F. Tyrrell. 1979. Methane production of dairy cows. J. Dairy Sci. 62:1583-1586.

National Research Council. 1989. Nutrient Requirements of Dairy Cattle. 6th rev. ed. Natl. Acad. Sci., Washington, DC.

National Research Council. 2001. Nutrient Requirements of Dairy Cattle. 7th rev. ed. Natl. Acad. Sci., Washington, DC.

Oba, M., and M. S. Allen. 1999. Evaluation of the importance of the digestibility of neutral detergent fiber from forage. Effects on dry matter intake and milk yield of dairy cows. J. Dairy Sci. 82:589-596.

Onetti, S. G., R. D. Shaver, M. A. McGuire, and R. R. Grummer. 2001. Effect of type and level of dietary fat on rumen fermentation and performance of dairy cows fed corn silage-based diets. J. Dairy Sci. 84:2751-2759.

Palmquist, D. L. 1991. Influence of source and amount of dietary fat on digestibility in lactating cows. J. Dairy Sci. 74:1354-1360.

Rogers, J. A., C. L. Davis, and J. H. Clark. 1982. Alteration of rumen fermentation, milk fat synthesis, and nutrient utilization with mineral salts in dairy cows. J. Dairy Sci. 65:577-586.

SAS User's Guide: Statistics. 1985. Version 5 Edition. SAS Inst. Inc., Cary, NC.

Schauff, D. J., J. P. Elliott, J. H. Clark, and J. K. Drackley. 1992. Effects of feeding lactating dairy cows diets containing whole soybeans and tallow. J. Dairy Sci. 75:1923-1935.

Smith, W. A., and B. Harris, Jr. 1992. The influence of forage type on the production response of lactating dairy cows supplemented with different types of dietary fat. Prof. Anim. Sci. 8(3):7-21.

Smith, W. A., B. Harris, Jr., H. H. Van Horn, and C. J. Wilcox. 1993. Effects of forage type on production of dairy cows supplemented with whole cottonseed, tallow, and yeast. J. Dairy Sci. 76:205-215.

Sukhija, P. S., and D. L. Palmquist. 1988. Rapid method for determination of total fatty acid content and composition of feedstuffs and feces. J. Agric. Food Chem. 36:1202-1206.

Udén, P., P. E. Colucci, and P. J. Van Soest. 1980. Investigation of chromium, cerium, and cobalt as markers in digesta. Rate of passage studies. J. Sci. Food Agric. 31:625-632.

Van Soest, P. J., J. B. Robertson, and B. A. Lewis. 1991. Methods for dietary fiber, neutral detergent fiber, and nonstarch polysaccharides in relation to animal nutrition. J. Dairy Sci. 74:35833597.

Weisbjerg, M. R., Hvelplund, T., and C. F. Børsting. 1992. Digestibility of fatty acids in the gastrointestinal tract of dairy cows fed with tallow or saturated fats rich in stearic acid or palmitic acid. Acta Agric. Scand., Sect. A, Anim. Sci. 42:115-120.

Williams, C. H., D. J. Daniel, and O. Iiasmaa. 1962. The determination of chromic oxide in feces samples by atomic absorption spectrophotometry. J. Agric. Sci. 59:381-385. 